\title{
Affirming Divine Providence and Limiting the Powers of Saints: the Byzantine Debate about the Term of Life (6th-11th Centuries)
}

\author{
Dirk Krausmüller \\ Universität Wien \\ dkrausmuller@hotmail.com
}

\begin{abstract}
One of the chief characteristics of Byzantine culture in the early Middle Age was the willingness to engage in sometimes fierce debates. The best known of these debates, the controversy about the veneration of images, has been studied by many scholars and is now well known. The same cannot be said about another contentious issue, the question of whether the time of one's death was fixed from eternity or whether it could be changed. In the late 1970s Leendert Gerrit Westerink and Giuseppe Zanetto published critical editions of two major contributions to the debate, a disputation by Theophylact Simocatta and a dialogue by Patriarch Germanus of Constantinople. Yet this did not lead to sustained engagement with the texts. The only discussion is found in Wolfgang Lackner's edition of a much later treatise by Nicephorus Blemmydes. In the introduction to his edition Lackner identified numerous relevant primary sources dating to the fourth to twelfth centuries, proposed a rough classification and discussed some of the arguments used by the authors. What is still missing is a reconstruction of the historical context of the debate. The present article seeks to fill this gap. It considers not only treatises about the term of life but also Biblical commentaries, homilies, hymns, letters and saints' lives that can throw light on the debate.
\end{abstract}

\section{Keywords}

providence - term of life - saints - intercession - Byzantine

Some time in the early seventh century Theophylact Simocatta, a high state official and littérateur who is best known as the author of a historical work, wrote a short text devoted to the question of why a human being dies at a 
particular point of his or her life. ${ }^{1}$ This text takes the form of a prosopopoiia. ${ }^{2}$ In the first part Theophylact attributes to two fictional characters diametrically opposing views. One contends that the lifespans of all human beings are fixed from eternity whereas the other claims that there are no preordained limits at all. In the second part he has two further characters judge the merits of the two arguments. The verdict is presented as the golden mean between the two extremes, which are considered equally reprehensible: God predetermines the hour of death for everyone but can also change it when he wishes to punish or reward particular individuals. There can be little doubt that Theophylact created this scenario in order to demonstrate his prowess as a rhetorician. However, this does not mean that we can dismiss the text as mere play. Theophylact did not invent the positions and the various arguments that were adduced in their support but took his inspiration from a contemporary debate. This debate was still going on a hundred years later when patriarch Germanus of Constantinople, the author of numerous sermons in honour of Christ and Mary, wrote a rhetorically embellished dialogue in which he defended the notion of a fixed term of life against a contemporary critic. ${ }^{3}$

That a text of this kind was produced in the early eighth century is highly significant because at that time literary production had almost come to a standstill. ${ }^{4}$ Equally significant is the fact that Theophylact's and Germanus' writings are the first of their kind. Nothing comparable is found in the much more substantial literary legacy of the previous centuries. When earlier authors engaged with the topic they did not make use of the dialogue form but contented themselves with setting out their own views, most likely because

1 Edited by G. Zanetto, Teofilatto Simocatta. De vitae termino (Koinonia. Collana di Studi e Testi, 3), Naples, 1979, pp. 37-52, with Italian translation on pages 53-64; and by Ch. Garton and L.G. Westerink, Theophylactus Simocates, On Predestined Terms of Life (Arethusa Monographs, 6), Buffalo, NY, 1978, pp. 2-31, with facing English translation.

2 On the literary form of the text see the introductions of Zanetti, pp. 10-15, and Garton and Westerink, pp. ix-xi. On the author see M. Whitby, The Emperor Maurice and his Historian: Theophylact Simocatta on Persian and Balkan Warfare (Oxford Historical Monographs), Oxford, 1988, esp. pp. 28-51.

3 Edited by Ch. Garton and L.G. Westerink, Germanos, On Predestined Terms of Life (Arethusa Monographs 7), Buffalo, NY, 1979, pp. 2-66, with facing English translation. On the author see D. Stein, "Germanos I. (715-730)," in: Die Patriarchen der ikonoklastischen Zeit, ed. R.-J. Lilie (Berliner Byzantinische Studien, 5), Frankfurt a. M., 1999, pp. 5-21.

4 On literary production in the so-called Dark Age see A. Kazhdan, L. Sherry and Ch. Angelidi, A History of Byzantine Literature (650-850) (Institute for Byzantine Research, Research Series 2), Athens, 1999, esp. pp. 137-165. 
they did not target other Christians but pagans, astrologers on the one hand and 'Epicureans' on the other. ${ }^{5}$

In-depth study of the two texts permits us to trace the emergence of a new discourse with its own rules and conventions. This discourse is centred on one Patristic proof text, taken from Basil of Caesarea's sermon Quod deus non sit auctor malorum:

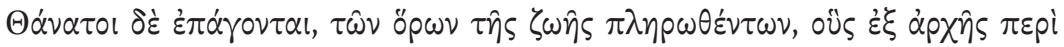

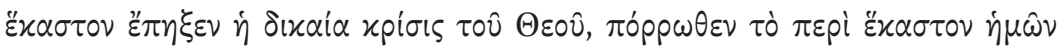

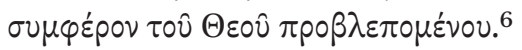

Deaths are brought on when the terms of life are completed, which the just judgement of God has fixed for each one from the beginning, since God foresaw from afar what would be profitable for each one of us.

By the early eighth century this passage had become the subject of a lively debate. This is evident from Germanus' text where the patriarch's adversary exclaims:

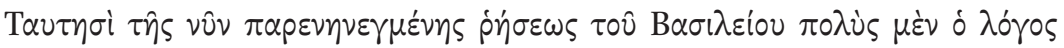

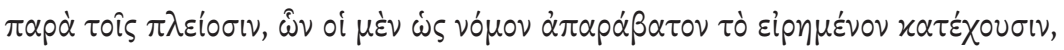

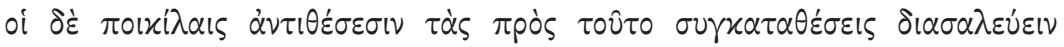
$\pi \varepsilon 1 \rho \hat{\omega} \nu \tau \alpha{ }^{7}{ }^{7}$

Regarding this statement of Basil, which you have just adduced, there is, among most people, a great deal of discussion. Some hold what he has said as an irrefragable law, whilst others try to undermine the votes of assent given to it through a variety of opposing views. ${ }^{8}$

5 This does not mean that the two authors did not make use of earlier texts. Theophylact, for example, puts into the mouth of the opponent of a fixed term of life passages from Gregory of Nyssa's treatise De fato, which is directed against paganism. See the introduction to Zanetto, De vitae termino, 21-22.

6 Basil of Caesarea, Quod deus non sit auctor malorum, $P G$ 31, col. 333B. In the following the focus will be on interpretations of Basil's dictum. Other arguments will not be considered. For a discussion of them see Lackner, p. liv, and the introductions to the editions.

7 Germanus, Terms of Life, ed. Garton and Westerink, p. 14.1-6.

8 Germanus, Terms of Life, tr. Garton and Westerink, p. 15. 
Significantly, the passage is neither quoted nor alluded to in texts from the fifth and sixth centuries. It makes its first appearance in Theophylact's rhetorical exercise. Theophylact puts into the mouth of the defender of a fixed term of life the following argument:

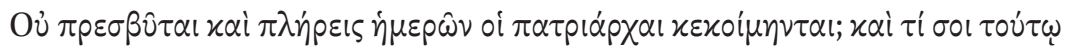

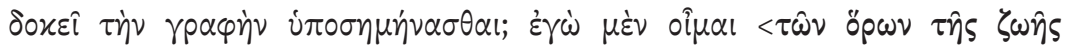

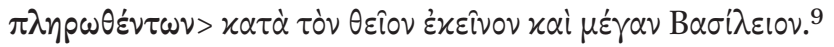

Old and full of days the patriarchs have been, have they not, when laid to rest. What do you think scripture implies by this? To my mind it implies, to quote the great Basil, 'when the terms of life were completed. ${ }^{10}$

Here the proper meaning of a Biblical phrase, 'full of days', is established through reference to Basil. Significantly the opposing party also engages with Basil's statement:

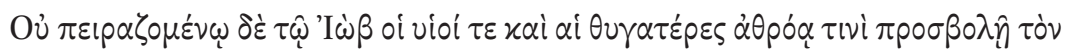

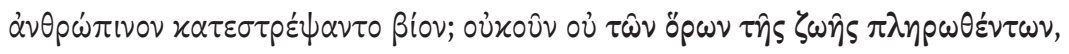

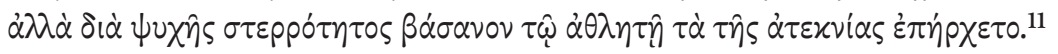

And when Job was being put to the ordeal did not his sons and daughters have their human lives brought to an end by a stroke that affected them collectively? It was not because the terms of life were completed that deprivation of children was brought to bear upon that champion in suffering but by way of a test of his steadfastness of soul. ${ }^{12}$

Here it is implied that Biblical passages contradict what Basil has to say and that Basil must therefore be discounted as an authority in the debate. These strategies also make an appearance in Germanus' dialogue. There the defender of a changeable term of life quotes numerous verses from the Bible that seem to prove his point; and his opponent invariably declares that these verses cannot be taken at face value but have a deeper meaning that does not clash with the statement in Quod deus non sit auctor malorum. ${ }^{13}$

9 Theophylact, Terms of Life, ed. Zanetto, p. 40.82-85; ed. Garton and Westerink, p. 7.28-8.3.

10 Theophylact, Terms of Life, tr. Garton and Westerink, p. 9.

11 Theophylact, Terms of Life, ed. Zanetto, p. 45·75-79; ed. Garton and Westerink, p. 16.17-21.

12 Theophylact, Terms of Life, tr. Garton and Westerink, p. 17.

13 Germanus, Terms of Life, ed. Garton and Westerink, p. 12.27, p. 18.27. 
In Germanus' dialogue we also find a discussion about how much authority should be accorded to Basil's words. Unsurprisingly Germanus himself emphasises Basil's contribution to Trinitarian theology. He implies that Basil who even knew the true nature of the divinity cannot be wrong in his other teachings. ${ }^{14}$ His adversary chooses a radically different strategy. He lays down rules for the use of Patristic proof texts in general: they should only be accepted if they contain arguments that can be judged by human reason. ${ }^{15}$ Such a stance was highly unusual at a time when participants in theological debates supported their points of view with strings of quotations from the Fathers. However, not everybody who was unhappy with Basil's statement went so far. The introductory remarks of Germanus' dialogue reveal the existence of other responses:

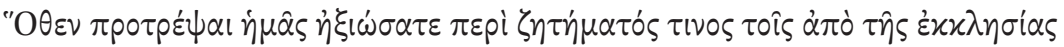

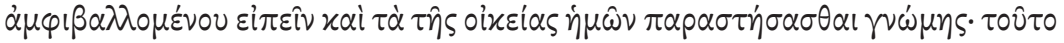

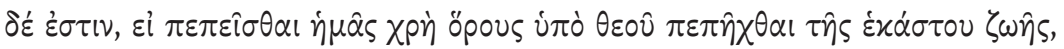

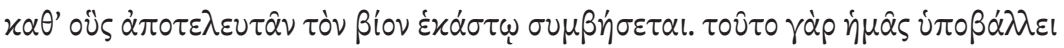

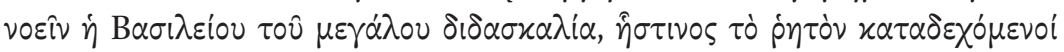

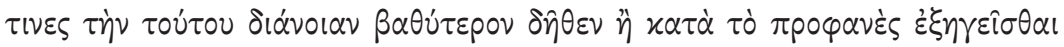

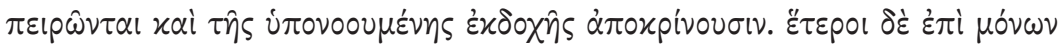

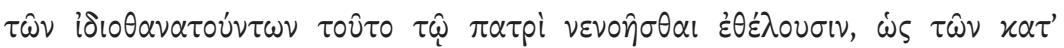

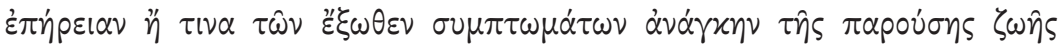

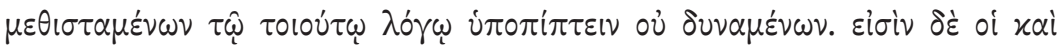

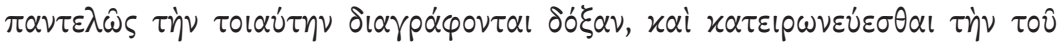

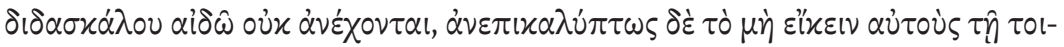

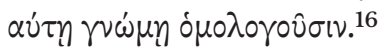

You were therefore moved to suggest that I should speak on a certain question debated by churchmen and render my own opinion in the matter; which is, whether we must hold it as a conviction that God has fixed terms for the life of each individual, in accordance with which it will come about that each one ends his life. This is suggested to us by the teaching of Basil the Great, though some people take the letter of his teaching and then try to explain his meaning on a deeper level, as they claim, than the obvious one, separating it from the interpretation that naturally suggests itself. Others will have it that Basil has meant this only

\footnotetext{
14 Germanus, Terms of Life, ed. Garton and Westerink, p. 14.7-19.

15 Germanus, Terms of Life, ed. Garton and Westerink, p. 14.20-28.

16 Germanus, Terms of Life, ed. Garton and Westerink, pp. 4.25-6.10.
} 
of those who die a natural death, in the belief that those who depart the present life through foul play or some constraint of external circumstances cannot come within the scope of such a pronouncement. And some again strike out such an opinion altogether; they refuse to feign reverence for their teacher, and openly admit that they do not concur in such a judgement. ${ }^{17}$

Germanus' description of the debate shows that many of those who rejected the notion of a fixed term of life nevertheless felt the need to engage with Basil's statement. One explanation was particularly popular. It was argued that Basil did not refer to the life-spans of individuals but made a general comment about the fact that human beings are mortal, which was irrelevant to the debate. This argument is already alluded to in Theophylact's rhetorical exercise. ${ }^{18}$ It is then set out in full in Germanus' dialogue:

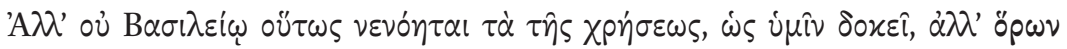

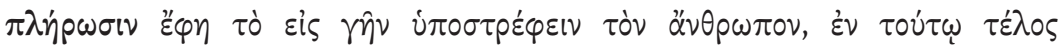

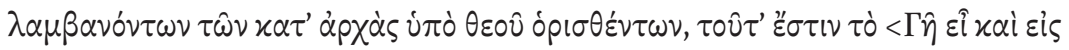
$\gamma \hat{\eta} \nu \dot{\alpha} \pi \varepsilon \lambda \varepsilon \dot{\sigma} \sigma \eta{ }^{19}$

But the passage is not meant by Basil in the way your side thinks. Rather, by the completion of terms he meant man's returning to earth, since it is herein that an end overtakes those who were determined at the outset by God, that is 'Earth you are, and to earth you shall depart.'20

Significantly the same reasoning is found in the Questions and Answers of Anastasius of Sinai who calls the topic a 'universal problem':

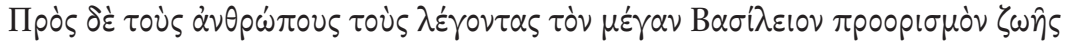

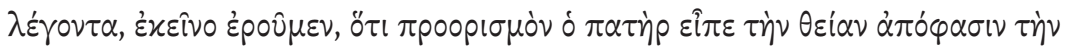

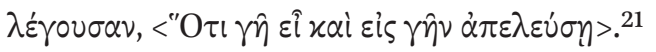

17 Germanus, Terms of Life, tr. Garton and Westerink, pp. 5, 7 .

18 Theophylact, Terms of Life, ed. Zanetto, p. 49.40-41, ed. Garton and Westerink, p. 24.20-23:

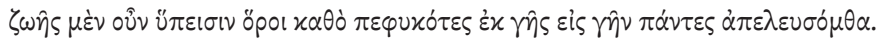

19 Germanus, Terms of Life, ed. Garton and Westerink, p. 16.23-26.

20 Germanus, Terms of Life, tr. Garton and Westerink, p. 17.

$21 \quad$ Cf. Anastasius, Questions and Answers, 16.6, ed. J.A. Munitiz and M. Richard, Anastasii Sinaitae Questiones et Responsiones (Corpus Christianorum. Series Graeca, 59), Turnhout, 2006, p. 27.53-56. 
To the people who say that Basil the Great speaks about a predetermination of life, we shall say that what the father meant by predetermination was the judgement that says 'Earth you are and to earth you shall depart'.

This text shows that around the year 700 Basil's statement was discussed not only in Constantinople but also in the East. We can be sure that there once existed more contributions to the debate, which have not come down to us or have not yet been identified. Here I will only point to the teachings of PseudoEusebius of Alexandria, which have much in common with the Questions and Answers literature and may date to the same period. ${ }^{22}$ In this text Eusebius' interlocutor asks why some people die from unnatural causes such as drowning. He is told that drowning can be caused by the devil. Then follows the comment:

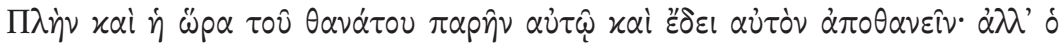

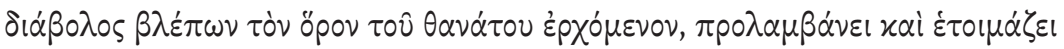

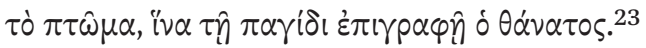

Besides the hour of death had also come for him and he would have died anyway but the devil who sees the term of death coming, intervenes and prepares the fall in order that the death be attributed to the snare.

This argument is clearly a response to one of the positions mentioned in Germanus' text, namely that only those who die a natural death have a predetermined lifespan. Pseudo-Eusebius declares that in the case of unnatural deaths only the manner of death is influenced by the devil whereas the term of life itself is fixed by God.

The evidence presented so far shows that in the seventh and early eighth centuries the rules of the discourse were set by the champions of a fixed term of life. They largely succeeded in establishing the quotation from Basil's sermon as a shibboleth of right belief. Interestingly the defenders of a changeable term of life did not respond in kind. Explicit quotations from other Patristic authors that could challenge Basil's statement or modify its tenor do not feature in the debate at all. Anastasius adapts arguments from a sixth-century

22 On the fictitious patriarch Eusebius of Alexandria, see J. Leroy and F. Glorie, "Eusèbe d'Alexandrie, source d' Eusèbe de Gaule," Sacris erudiri, 19 (1969-1970), pp. 33-70, esp. 47.

23 Pseudo-Eusebius, De iis qui in laqueis impliciti pereunt, PG 86.1, col. 352A 
text, a sermon by Leontius of Constantinople, but he does not disclose the identity of his source. ${ }^{24}$

The quotation from Basil gained such importance for the defenders of a fixed term of life because it contained a pithy summary of their worldview. They believed that like everything else the time of death of each individual was fixed from eternity in accordance with a divine plan that was beneficial for the dying and for everybody else. By contrast, their opponents claimed that such a view was irreconcilable with Christianity. Theophylact's rhetorical exercise shows what they suspected:

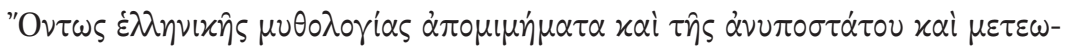

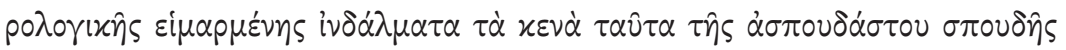
$\tau \varepsilon \rho \alpha \tau 0 \lambda \circ \gamma \eta \dot{\eta} \mu \alpha \tau \alpha^{25}$

Mimickings of Greek mythology they are indeed, and wraiths of insubstantial metaphysical destiny, those empty monstrosities you utter out of such frivolous earnest. ${ }^{26}$

Here the notion of a fixed term of life is linked to paganism and more specifically to astrological determinism. This was not a new argument. It had already been used in the fourth and fifth centuries by Diodore of Tarsus, Theodore of Mopsuestia and Theodoret of Cyrus, and in the sixth century it had made its appearance in the sermon of Leontius of Constantinople that I have mentioned earlier. ${ }^{27}$ This shows clearly that the defenders of a changeable term of life merely recycled an already existing polemic. The only difference was that the opponents had changed. Instead of pagan astrologers they were now Christians who emphasised the universality of divine providence. This view, too,

24 Leontius of Constantinople, Homilia x, ed. C. Datema and P. Allen, Leontii presbyteri Constantinopolitani homiliae (Corpus Christianorum. Series Graeca, 17), Turnhout and Leuven, 1987, pp. 329-330.339-350, directed not against Christians but against pagans, as is usually the case in Late Antiquity.

25 Theophylact, Terms of Life, ed. Zanetto, p. 47.124-126, ed. Garton and Westerink, p. 20.15-17.

26 Theophylact, Terms of Life, ed. Garton and Westerink, p. 21.

27 W. Lackner, Nikephoros Blemmydes. Gegen die Vorherbestimmung der Todesstunde. Einleitung, Text, Übersetzung und Kommentar (Corpus Philosophorum Medii Aevi. Philosophi Byzantini, 2), Athens-Leiden, 1985, pp. xliv-lii. 
was not new: after all it had been expressed by Basil in his sermon. ${ }^{28}$ However, there is no sign of a polemic that targeted other Christians who denied the existence of a fixed term of life. Such polemic only seems to have started in the second half of the sixth century. This we can conclude from Theophylact's rhetorical exercise. As we have seen it dates to the early seventh century and already presupposes a lively debate. Significantly, the defenders of a fixed term of life never react to the accusation that their views smack of pagan determinism. This suggests that the old arguments had lost their force.

The real issue was how one should conceptualise the Christian God. The defenders of a changeable term of life envisaged a deity that responds to events in the created order. This view they shared with the authors of the Christian Scriptures, which explains why they made their case primarily through recourse to Biblical verses. By contrast, their opponents followed the teachings of philosophically minded theologians such as Basil who found unacceptable the notion that God could change his mind. We encounter the latter point of view in Germanus' dialogue. ${ }^{29}$ However, it is most clearly expressed in another text, John of Damascus' treatise Contra Manichaeos:

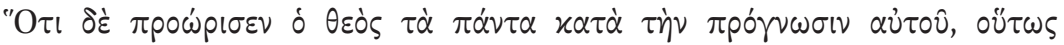

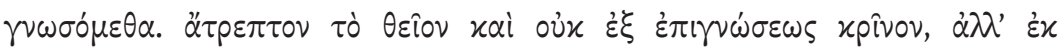

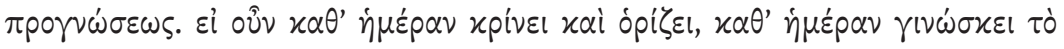

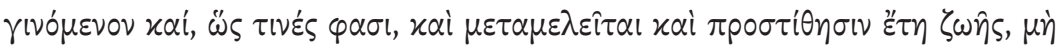

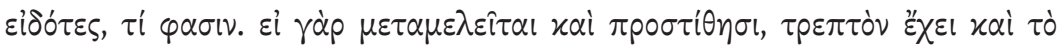

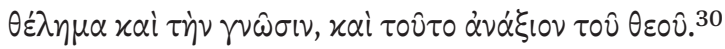

28 Significantly Lackner, pp. xliv-lii, lists only one more example for acceptance of a fixed term of life besides Basil, Athanasius, Apologia de fuga, 14.3-7, ed. J.M. Szymusiak, Athanase d'Alexandrie, Deux apologies (Sources Chrétiennes, 56), Paris, 1958, pp. 149-154. However, his position cannot be compared with that of Basil since he declares that God can change the time of death. This suggests that Basil's position was not shared by many others. By contrast, the list of those who rejected a fixed term of life outright could be extended. See for example Barsanuphius, Letter 642, ed. F. Neyt, P. de Angelis-Noah and L. Regnault, Barsanuphe et Jean de Gaza, Correspondance, III. Aux laïcs et aux évêques. Lettres 617-848, Introduction, texte critique, notes et index (Sources Chrétiennes, 468), Paris, 2002, p. 68.

29 Germanus, Terms of Life, ed. Garton and Westerink, p. 30.17-22.

30 John of Damascus, Contra Manichaeos, 8o, ed. B. Kotter, Die Schriften des Johannes von 
That God has predetermined all things according to his foreknowledge, we will know thus: the divine is unchangeable and does not judge from after-knowledge but from fore-knowledge. If, then, he makes judgements and determinations day by day, he learns what happens every day and, as some say, even repents and adds years of life. Those people do not know what they are saying: for if he repents and adds, he has also a changeable will and knowledge, and this is unworthy of God.

The context in which such statements are made is discussions of the specific case of the Jewish king Hezekiah. According to the Bible, Hezekiah was told by God that he was to about to die. He then turned to prayer and eventually received the following response from God:

"H

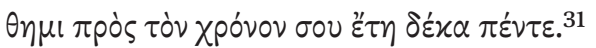

I have heard the voice of your prayer and seen your tears. Behold, I add fifteen years to your time.

Both Germanus and John of Damascus declare that this story cannot be taken at face value because it would fly in the face of common notions about God. They argue that Hezekiah would have lived for another fifteen years in any case because this was his allotted timespan, and that the announcement of the king's imminent death was just a ruse, which God used in order to get him to repent. ${ }^{32}$

The crucial role that the case of Hezekiah plays in the arguments of Germanus and John shows that the debate was not just a quarrel between theologians about how one should conceptualise God. Many Christians shared Hezekiah's belief that it was possible to stave off death through prayers, offered either by the dying themselves or by others who interceded for them. This belief had a long history. Already in the third century Origen had stated in his homilies on Jeremiah:

Damaskos, Iv, Liber de haeresibus. Opera polemica (Patristische Texte und Studien, 22), Berlin-New York, 1981, pp. 394-395.1-6.

32 See Lackner, Gegen die Vorherbestimmung, p. lv. 


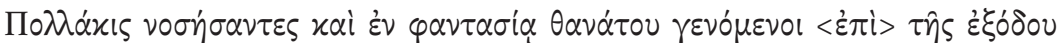

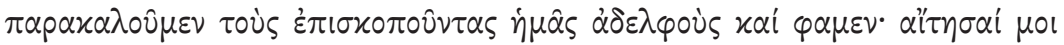

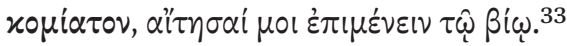

Often when we have fallen ill and have imagined that we are going to die we beg at the departure the brothers who look after us and say: 'Beg that I am given a reprieve, beg that I may stay in this life.'

The practice seems to have been well entrenched in Late Antiquity. ${ }^{34}$ In the fifth century it is mentioned in Palladius' Lausiac History. Palladius tells his readers that the young Evagrius fell ill during his stay with Melania the Elder in Jerusalem and then narrates the following interaction:

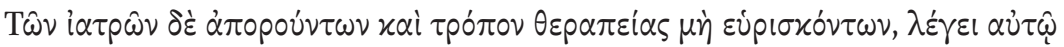

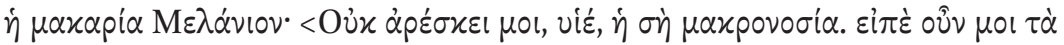

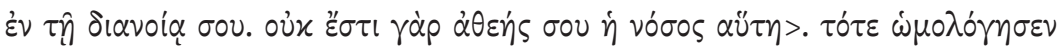

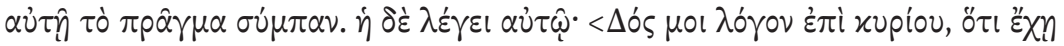

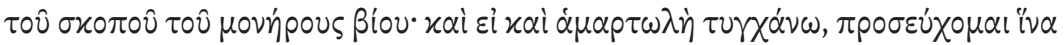

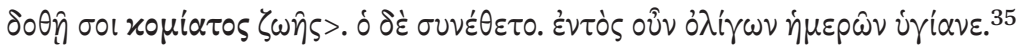

When the physicians were at a loss and could not find a cure, the blessed Melania said to him: 'I do not like this lengthy illness of yours, son. Tell me then what is in your mind. For this illness of yours is not without a divine aspect.' Then he confessed the whole matter to her. And she said to him: 'Promise me in the name of the Lord, that you hold fast to the plan to become a monk. And even though I am a sinner, I will pray that a reprieve of life be given to you.' He promised, and within a few days he recovered.

It is evident that such prayers would be without purpose if the term of life were fixed. Indeed, just this point is made by the authors of Questions and Answers. These authors are particularly concerned with the validity of intercessory prayers. In a collection attributed to Athanasius of Alexandria we read:

33 Origen, In Jeremiam homiliae, 17.6, ed. P. Nautin, Origène. Homélies sur Jérémie, II (Sources chrétiennes 238), Paris, 1977, p. 174.25-28.

34 For the terminology used in the two texts see A. Adler, Lexicographi Graeci, I.3, Suidae

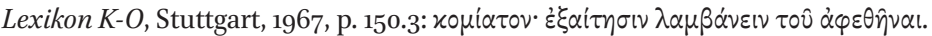

Palladius, Lausiac History, 38, ed. C. Butler, The Lausiac History of Palladius. A Critical Discussion Together with Notes on Early Egyptian Monasticism, Cambridge, 1898, vol. I, pp. 119.18-120.4. 


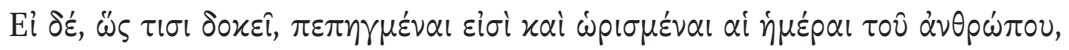

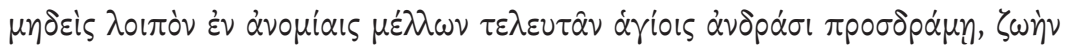

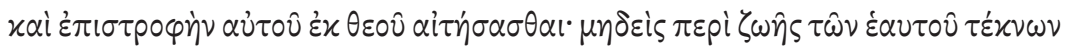

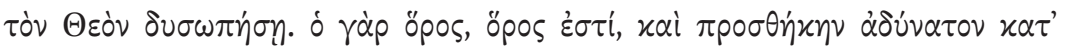

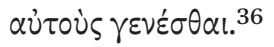

If as some think, the days of the human being are fixed and determined, nobody who is about to die in a state of sin will henceforth run to holy men that they may ask from God his life and his return; nobody would entreat God about the life of his own children. For the term is a term and according to them there can be no addition.

Here mention is made not only of ordinary Christians praying for those who are dear to them but of the saints as a specific group whose intercessions are particularly powerful since they have the ear of God. This detail is also found in the collection of Anastasius of Sinai and must therefore go back to the common source of both texts:

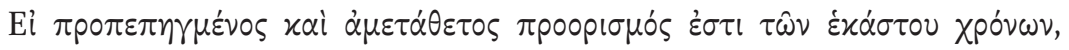

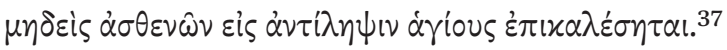

If there is a fixed and unchangeable predetermination of the years of each one, let nobody call upon saints for help when he is ill.

This raises the question: did the defenders of a fixed term of life actively seek to limit the intercessory powers of the saints? The writings of Theophylact and Germanus give us no answer. Although the defenders of a changeable term of life point to the efficacy of intercessory powers of the righteous as proof of their view, their opponents never respond to this argument. ${ }^{38}$ The reasons for this silence are not clear: the authors may have wished to sidestep a contentious issue, but it is also possible that they did not consider it relevant in a purely theological discussion.

36 Ps-Athanasius, Questions and Answers, 130, PG 28, col. 668C3-9.

37 Anastasius of Sinai, Questions and Answers, 16.2, ed. Richard and Munitiz, p. 24.11-13. See also J.A. Munitiz, "The Predetermination of Death: The Contribution of Anastasios of Sinai and Nikephoros Blemmydes to a Perennial Byzantine Problem," Dumbarton Oaks Papers, 55 (2001), pp. 9-20.

38 See especially Theophylact, Terms of Life, ed. Zanetto, p. 50.68-69, ed. Garton and Westerink, p. 26.20-21. 
Fortunately for us other writings can fill the gap. Of particular significance are commentaries on Ecclesiastes 8:8:

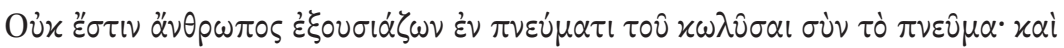

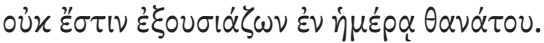

No human being is powerful in the spirit so that he may hinder the spirit, and nor is there one who is powerful at the hour of death.

The first extant interpretation of these verses was written in the sixth century by the Alexandrian deacon Olympiodorus:

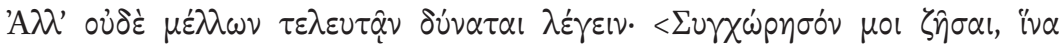

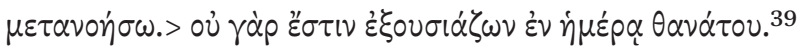

Nor can somebody who is about to die say: 'Grant me to live in order that I repent.' For there is noone who is powerful at the hour of death.

Here we find a clear rejection of the belief that death could be staved off through prayer. A much more elaborate expression of the same view is then found in a commentary dating to the seventh century:

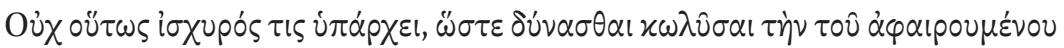

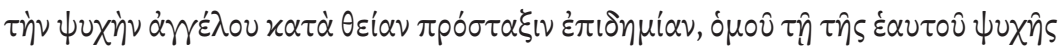

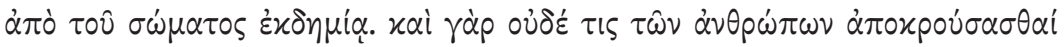

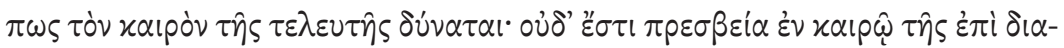

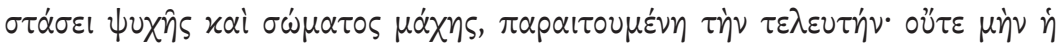

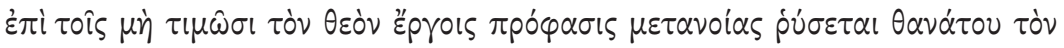

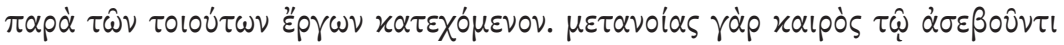

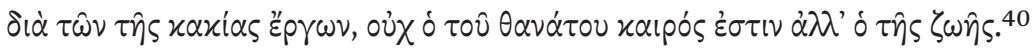

Nobody is so powerful that he can hinder the arrival of the angel that takes away the soul at God's command simultaneously with the departure of one's own soul from the body. And neither can a human being somehow stave off the time of the end. Nor is there intercession at the

39 Olympiodorus, Commentarii in Ecclesiasten, PG 93, col. 577 $\mathrm{C}_{3}-5$.

40 Anonymus, Scholia in Ecclesiasten, 8, ed. S. Luca, Anonymus in Ecclesiasten commentarius qui dicitur catena trium patrum (Corpus Christianorum. Series Graeca, 11), Turnhout, 1983, p. 59.39-50. 
time of the struggle that leads to the separation of soul and body, which could beg off the end. Nor indeed will the pretext of repentance over works that do not honour God save from death the one who is caught in such works. For him who has been impious through works of evil the time of repentance is not the time of death but that of life.

Unlike Olympiodorus, the anonymous author speaks not only of the prayers of the dying but also of intercession on behalf of the dying and he denies explicitly that such intercession could be effective. His argument alludes to a particular practice, the meditation of death ${ }^{41}$ This practice is described in the seventh-century Life of John the Almsgiver:

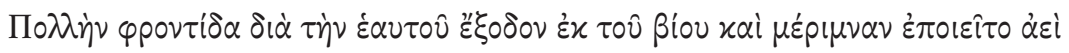

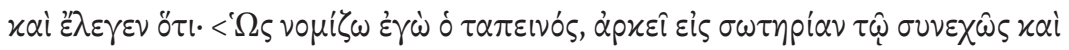

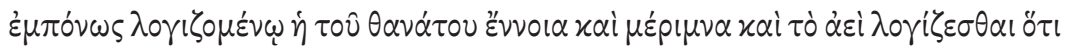

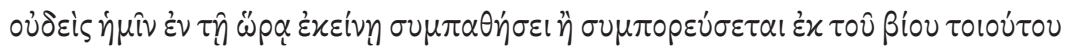

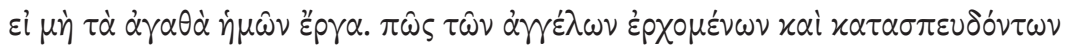

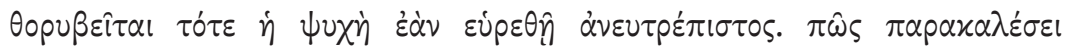

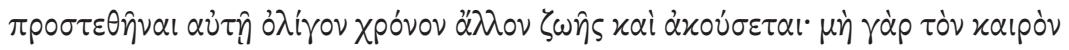

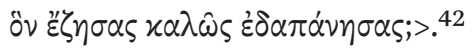

He was very anxious and worried about his own departure from this life and said: 'According to my humble opinion the meditation and worry about death is sufficient for salvation for him who continually and strenuously thinks about it, and so is also the continuous thought that nobody will suffer with us or go with us from this life apart from our good works. How troubled will the soul then be when the angels come rushing if it is found unprepared. How will it ask that a little more life be added to it, and it will hear: "Have you not used well the span of your life?"

Here fear of death is used as a means to effect moral improvement. The last hour can come all of a sudden and it is therefore necessary to be prepared at all times. This line of reasoning appears to have been quite popular in the seventh

41 See also V. Marinis, Death and the Afterlife in Byzantium: the Fate of the Soul in Theology, Liturgy and Art, New York-Cambridge, 2017, pp. 49-53.

42 Life of John of Cyprus, 43, ed. A.-J. Festugière and L. Rydén, Léontios de Néapolis, Vie de Syméon le Fou et Vie de Jean de Chypre (Bibliothèque archeeologique et historique, 95), Paris, 1974, p. 395.61-70. 
century because it is also found in a number of sermons. ${ }^{43}$ The affinities between the preachers and the champions of a fixed term of life are evident. Indeed, one can argue that the latter provided the conceptual framework on which the former could build their exhortations.

As far as we can tell none of the champions of a fixed term of life rejected the intercessions of saints in principle. Indeed, Germanus was a fervent worshipper of Mary who emphasised the efficacy of intercessory prayers in his sermons:

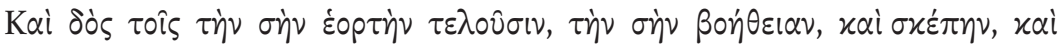

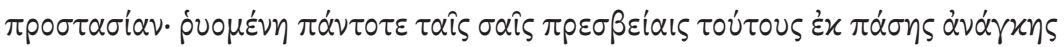

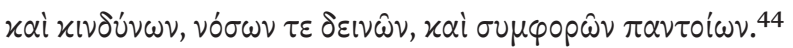

And give those who celebrate your feast today your help and shelter and protection, liberating them always through your intercessions from all constraints and dangers, terrible illnesses and all manner of mishaps.

Nevertheless, their view that the term of life could not be changed amounted to a limitation of the powers of saints as intercessors.

This raises the question: how did the authors of hagiographical texts respond to such views? After all it was their heroes who were regarded as having extraordinary powers of intercession. An episode that is relevant to our question is found in the Life of Theodore of Sykeon by the monk George Eleusius, which dates to the early seventh century:

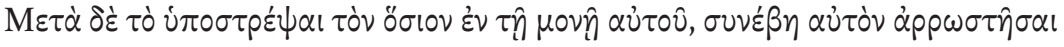

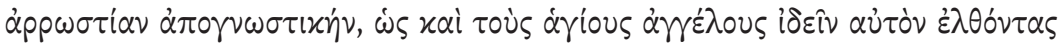

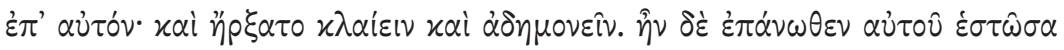

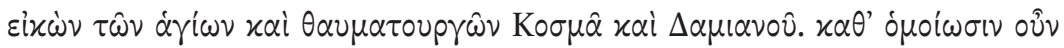

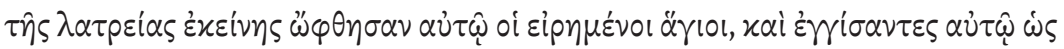

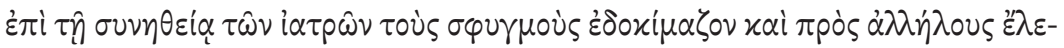

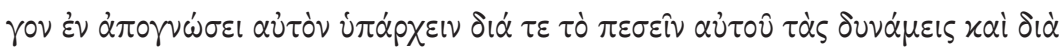

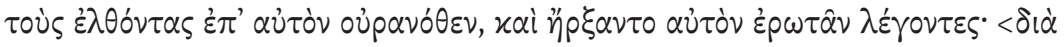

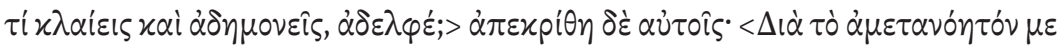




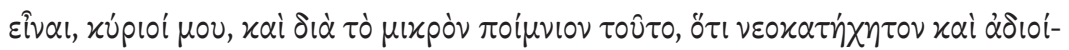

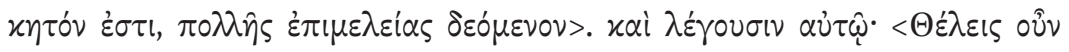

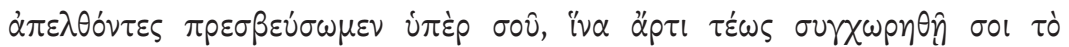

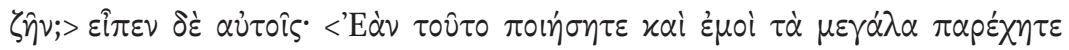

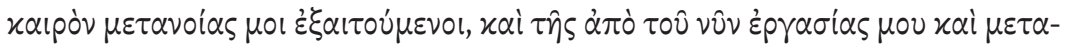

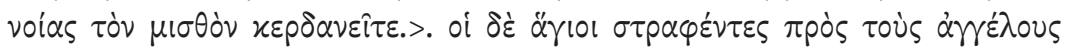

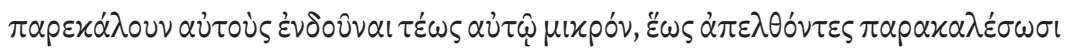

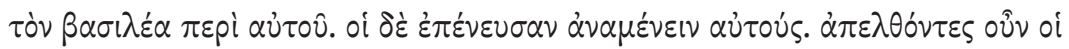

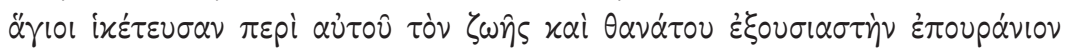

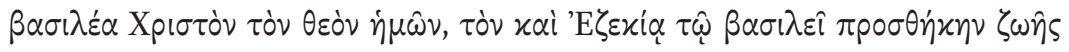

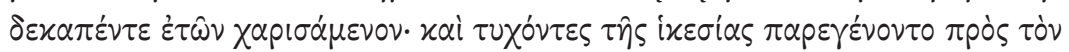

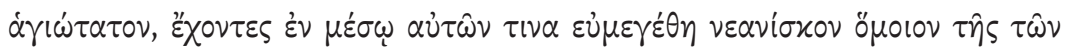

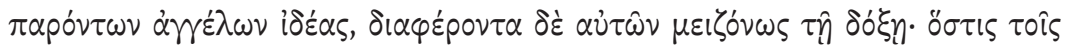

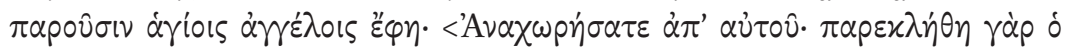

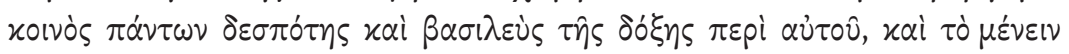

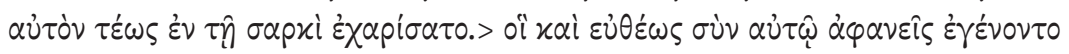

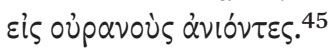

After the holy man had returned to his monastery, it came to pass that he fell ill without any chance of recovery, so that he even saw the angels coming towards him. And he began to weep and be troubled. There was standing above him an image of the holy wonderworkers Cosmas and Damian. In the likeness of this venerable image appeared to him the aforementioned saints, they approached him and tested his pulse as is the custom of physicians and said to one another that he was a hopeless case because his powers had sunk and because of those who had come to him from heaven. Then they began to ask: 'Why are you crying and troubled, brother?' And he answered them: 'Because I am without repentance, my lords, and because of this small flock, which is newly instructed and without guidance and thus needs much care.' And they said to him: 'Do you wish us to go and intercede on your behalf, so that for the time being life is granted to you?' And he said to them: 'If you do this and give me such great things, asking for a time of repentance, you will reap the reward of my activity and repentance from now on.' And the saints turned to the angels and asked them to give him a short reprieve until they had gone and entreated the king about him. They agreed to wait for them. And the saints went away and entreated on his behalf the lord of life and 
death, the heavenly king Christ, our God, who also granted King Hezekiah an addition of life of fifteen years. And when their entreaty was heard they came to the most holy one, having in their midst a tall youth who resembled the form of the present angels but differed from them greatly in splendour. He said to the holy angels who were present: 'Depart from here. For the common lord of all and king of glory has received an entreaty on your behalf and has granted him to stay in the flesh for the time being.' They immediately became invisible having ascended to heaven.

Although part of a biography of a saint, this episode conforms to the conventions of stories of miracles of the martyrs Cosmas and Damian, which had been written in the previous decades. There, too, the two figures frequently appear to people in the guise of physicians. ${ }^{46}$ However, the original template has been subtly modified. In the miracle stories the saints offer cures for people who have been given up by ordinary physicians. In the Life of Theodore of Sykeon, on the other hand, they come to the same conclusion as their colleagues, namely that the disease is incurable and will lead to death. This modification allows the hagiographer to integrate elements that we have encountered in texts about the meditation of death. Here, too, angels are sent in order to claim Theodore's soul. However, this regular procedure is now interrupted through an intervention of the martyrs who manage to persuade God to extend the saint's lifespan. It is evident that this is a response to texts about the meditation of death. Whereas the anonymous commentator on Ecclesiastes declares that in the hour of death no intercession is possible Theodore's hagiographer emphatically affirms the efficacy of intercessory prayers. Here we are clearly in the presence of an alternative discourse. As we have seen, the anonymous commentator makes the point that death cannot be staved off and that one must therefore repent at all times. By contrast, Theodore's hagiographer regards it as entirely possible that the saint's life can be extended in order to give him the opportunity to repent. Theodore was, of course, sinless and thus not actually in need of such a reprieve. However, for ordinary Christians the situation was entirely different: they were only too aware of their trespasses and therefore worried that they might end up in hell if they died a sudden death.

There can be little doubt that the episode was meant to be provocative. After all, it questioned the very basis of the programme of moral improvement

46 See Ph. Booth, "Orthodox and Heretic in the Early Byzantine Cult(s) of Saints Cosmas and Damian," in: An age of saints? Power, Conflict and Dissent in Early Medieval Christianity, ed. P. Sarris, M. Dal Santo, Ph. Booth, Leiden-Boston, 2011, pp. 114-128. 
that the promoters of the meditation of death had developed. What is less clear is whether Theodore's hagiographer was also aware of the debate about the term of life that is reflected in the writings of Theophylact Simocatta and Germanus and in the collections of Questions and Answers. He mentions the precedent of Hezekiah and models the saint's behaviour on that of the Israelite king. However, terms and concepts indicative of the debate are absent from the text.

In order to find these elements we need to look at another text from the first half of the seventh century, the Miracles of the martyrs Cyrus and John by Sophronius of Damascus, the later patriarch of Jerusalem. ${ }^{47}$ Sophronius tells the story of a devotee of the saints named George who was the beneficiary of their special care:

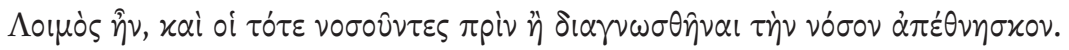

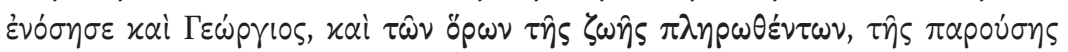

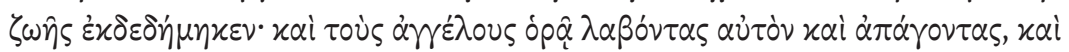

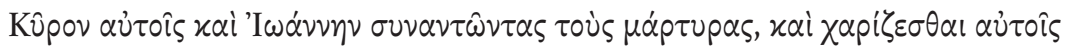

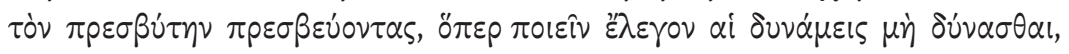

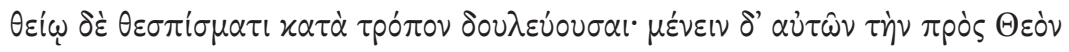

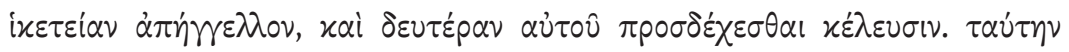

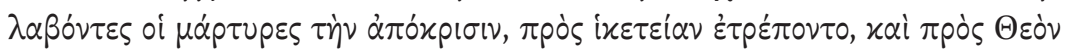

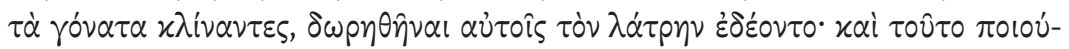

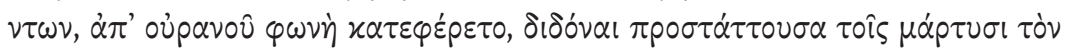

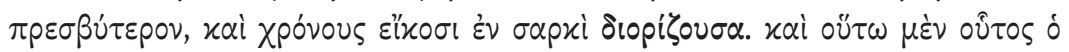

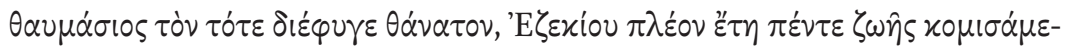

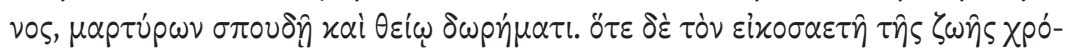

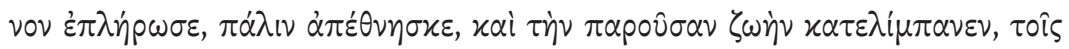

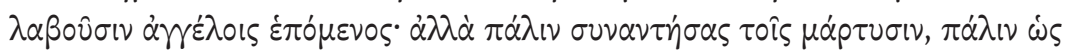

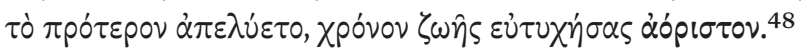

There was a plague, and those who were ill at that time died before the disease was diagnosed. And George also fell ill and departed from this life when the term of life had been completed. And he saw the angels taking him and leading him away and Cyrus and John meeting with them and

For an in-depth discussion of the text see $\mathrm{Ph}$. Booth, Crisis of Empire. Doctrine and Dissent at the End of Late Antiquity (Transformation of the Classical Heritage, 52), Berkeley-Los Angeles-London, 2014, pp. 44-89.

48 Sophronius, Miracles 51.10-12, ed. N. Fernandez Marcos, Los Thaumata de Sophronios. Contribution al estudio de la incubatio cristiana, Madrid, 1975, pp. 364-365. 
asking that the old man be granted to them. The powers said that they could not do this because they served the divine command to the letter, but announced that they would wait for their entreaty to God and would take a second command from him. Having received this answer, they turned to entreaty and, having bent their knees to God, begged that the worshipper be granted to them. And while they were doing this a voice came down from heaven, ordering to give the old man to the martyrs, and measuring out twenty years in the flesh. And thus the wondrous one escaped death at that time, having received five years more of life than Hezekiah, through the efforts of the martyrs and through a divine gift. When he had fulfilled the twenty-year-long time of his life, he died again, and left this present life, following the angels who had taken him, but he again met with the martyrs and was again liberated as before, having won an indeterminate time of life.

It is immediately evident that this episode bears a close resemblance to what we have found in the Life of Theodore of Sykeon. Here, too, the saints prevent the angels from taking the dying person's soul away, and the story of Hezekiah is appealed to as a precedent. No mention is made of the need for repentance. Instead, the focus is entirely on the mechanisms that ensure the extension of a person's lifespan. The phrase 'when the term of life had been completed' is a clear reference to Basil's dictum: we have already come across such a partial quotation in Theophylact's rhetorical exercise. This means that Sophronius is directly challenging the authority of Basil on which the defenders of a fixed term of life had built their case. Indeed, he goes even further. As we have seen, George's lifespan is extended twice, once for a number of years and once for an indeterminate time-span. The explanation for this curious reduplication is found in Theophylact's rhetorical exercise. There the contest between the two adversaries is judged by two arbiters who propose a compromise. They argue that God can extend the time of a person's life but only by setting a new term of life and not by giving a blank cheque:

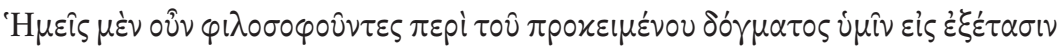

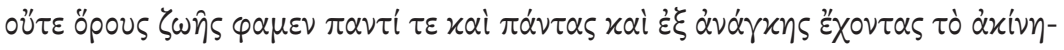

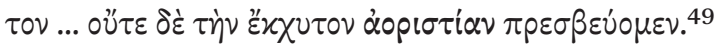

Well, then, for our part, cogitating upon the doctrine, which lies before you for examination, we neither affirm predestined terms of life, which 
all, for everyone, and of necessity retain their immovability ... but neither do we uphold that profuse indeterminacy. ${ }^{50}$

Here Theophylact lets his audience know that the latter option is impossible because only God is without bounds. Significantly, Sophronius had no such qualms. He was an extremist whose main concern it was to exclude everything that might have limited the powers of the saints.

It is evident that Sophronius and Theodore of Sykeon's hagiographer George Eleusius subscribe to the same world-view. They accept in principle that there is a fixed term of life for human beings but then argue that God makes exceptions when he is lobbied by certain privileged individuals. This world-view also finds expression in Germanus' dialogue. When the defender of the changeability of human lifespans is confronted with the argument that extending Hezekiah's life would run counter to common notions about God he protests:

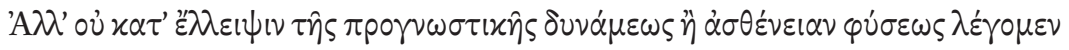

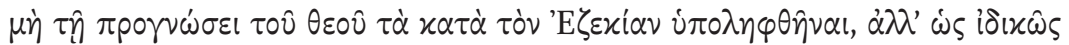

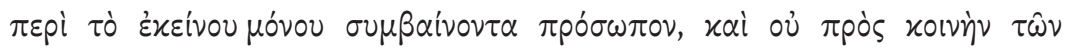

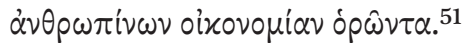

But it is not in terms of a failure of prognostic power or weakness of nature that we say that what happened in Hezekiah's case was not comprehended by God's foreknowledge. We speak of it as coming about specially in relation to the person of Hezekiah alone and not as related to the common dispensation of human fortunes in general. ${ }^{52}$

For the champions of a fixed term of life such a view was, of course, unacceptable. They argued that there can be no exception to divine providence:

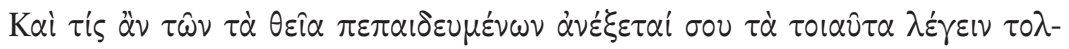

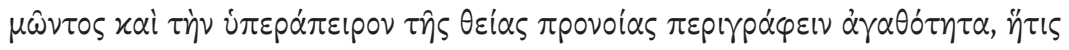

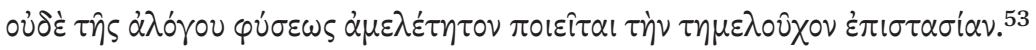

\footnotetext{
50 Theophylact, Terms of Life, tr. Garton and Westerink, p. 25.

51 Germanus, Terms of Life, ed. Garton and Westerink, p. 30.23-27.

$5^{2} \quad$ Germanus, Terms of Life, tr. Garton and Westerink, p. 31.

53 Germanus, Terms of Life, ed. Garton and Westerink, p. 30.28-31.
} 
And who is there among those qualified in divinity who will tolerate your daring to say such things and to circumscribe the more than infinite goodness of the divine providence, which does not leave unpractised the attentive care even of the nature that is without reason ${ }^{54}$

Here we have a clash between two diametrically opposing views. For one group this world is the best of all worlds: whatever happens is part of a perfect plan, which exists from eternity. ${ }^{55}$ If something seems less than perfect this is only a question of perception. Human beings do not have sufficient information, which would enable them to understand that the bad things they experience are in reality good for them. This leaves only one response: namely to trust in God and accept one's fate stoically. The members of the other group implicitly accept that the original plan may be faulty and therefore open to improvement. Accordingly, they take a more active stance: they attempt to change God's mind through prayers.

How far the devotees of the saints were prepared to go is evident from the Miracles of Artemius, which date to the second half of the seventh century. ${ }^{56}$ Here, too, a person is dying from the plague and the angels coming to collect her soul are prevented from doing their job by the saint:

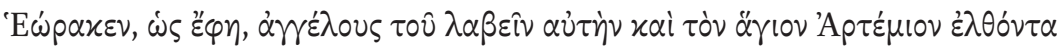

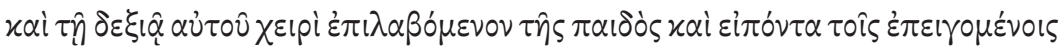

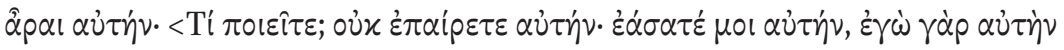

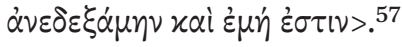

She saw, as she said, angels coming to take her and the holy Artemius approaching and gripping the girl with his right hand and saying to those who were rushing to take her: 'What are you doing? Do not take her. Leave her to me, for I have taken her on and she is mine.'

There is, however, a crucial difference: in this case the saint has already claimed the dying person for himself and resists the angels as executors of the divine

54 Germanus, Terms of Life, tr. Garton and Westerink, p. 31.

55 See the remarks of W. Blum, "Die Theodizee des Patriarchen Germanos I. von Konstantinopel," Vigiliae Christianae, 28 (1974), pp. 295-303.

56 For a discussion of the text see J. Haldon, "Supplementary Essay," in: The Miracles of St. Artemios. A Collection of Miracle Stories by an Anonymous Author of Seventh-Century Byzantium, ed. and tr. V.S. Crisafulli, J.W. Nesbitt (The Medieval Mediterranean, 13), LeidenNew York-Cologne, 1997, pp. 33-73.

57 Miracles of Artemius, 34, ed. Crisafulli and Nesbitt, p. 178.22-28. 
will. The author is clearly uneasy about such an infringement of God's power because he adds the comment:

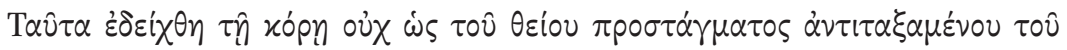

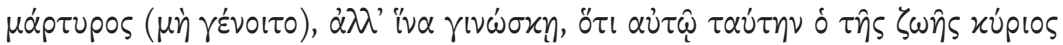
$\dot{\varepsilon} \chi \alpha \operatorname{pi}^{\prime} \alpha \tau \tau \sigma \pi \dot{\alpha} \lambda \alpha{ }^{58}$

This was shown to the girl not as if the martyr opposed himself to the divine command (far from it), but in order that she understood that the lord of life had long ago granted her to him.

It is not difficult to see from where the authors of miracle stories drew their inspiration. They simply projected ordinary human behaviour onto the celestial sphere. Just like human beings, God can change his mind and break his own rules if he so wishes. This view also makes its appearance in the Questions and Answers of Pseudo-Athanasius:

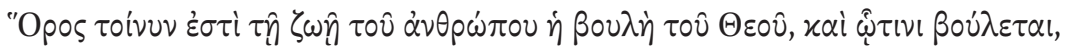

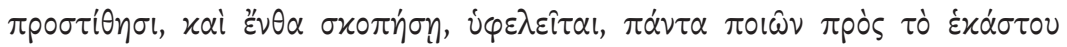

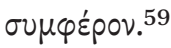

The term of life, then, is the counsel of God, and he adds where he wants it and takes away where he sees fit, doing everything to the profit of each one.

However, the narratives of George Eleusius and of Sophronius are a good deal more specific. There God is presented as an emperor who makes decisions and the angels as his officials who execute them. Other hagiographers, too, make this equation quite unselfconsciously. In a Life of Nicholas of Myra, for example, the dying saint addresses the angels with the following words:

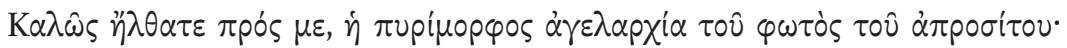

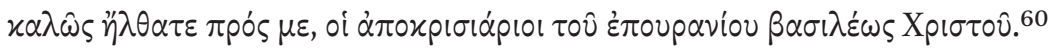

58 Miracles of Artemius, 34, ed. Crisafulli and Nesbitt, p. 180.4-7.

59 Pseudo-Athanasius, Questions and Answers, 113, PG, 28, col. 668C11-14.

6 Vita seu Periodoi, Rez. II, 19, ed. G. Anrich, Hagios Nikolaos. Der heilige Nikolaos in der griechischen Kirche. Texte und Untersuchungen. I: Die Texte, Berlin, 1913, p. 329.22-24. 
Welcome, fiery leaders of the host of the light of the unapproachable! Welcome, legates of the heavenly emperor Christ!

What such passages conjure up is an ordinary administrative process. An official comes to a city or a region with a command from the emperor, and a powerful local figure travels to the capital in order to have the command overturned. The following stage in the interaction can be explained in the same way. We have seen that in the texts of George Eleusius and Sophronius the new decision is communicated not by the saints themselves but rather through God's voice or through mediation of a more powerful angel. ${ }^{61}$ The obvious earthly counterparts would be an imperial document or a higher-ranking official. The Miracles of Artemius present us with an even more extreme case. They would have reminded contemporary audiences that powerful men could carve out for themselves a sphere where the law of the state was no longer valid. In this case it was the weakness of the emperor himself that undermined the proper functioning of the administration. We get the impression that the angels are not apprised of the fact that God has already ceded the rights over a person to the martyr.

The defenders of a fixed term of life rejected such projections from the earthly to the heavenly sphere as crude anthropomorphism. For them God could not change his mind or respond to the entreaties of human beings without losing his divine status. This gives the impression that their concept of God was abstract and bore no relation to this world. However, this impression may well be deceptive. After all, it is entirely possible to imagine an ideal state that corresponds to the notion of a changeless God. God would then correspond to an emperor who rules in accordance with fixed laws and through the mediation of a group of loyal officials and who is not amenable to manipulations by powerful private individuals. In such a scenario the initiative lies with the centre alone and the periphery passively accepts any command coming from there even if the benefits are not apparent. One is immediately reminded of the fraught political conditions of the seventh and early eighth centuries when the very existence of the empire was at risk. At that time the existing administrative structures in the provinces were becoming ever more dysfunctional and there was a real danger that the various regions would start governing themselves. However, with the exception of the Crimea and parts of Italy and Dalmatia this danger was averted because the emperors and the Constantinopolitan elite pushed through a policy of radical centralisation. From seals we know that special officials such as dioiketai and kommerkiarioi were sent out

61 See Vita seu Periodoi, 19, ed. Anrich, pp. 329-331, where the leader of the angels shows the dying saint the 'seal' of Christ. 
directly from the capital with the task to safeguard the financial needs of the centre. ${ }^{62}$

If this interpretation is correct one would expect the defenders of a fixed term of life to be found among the men who together with the rulers governed the state from the capital, and there is indeed some evidence to support this hypothesis. Germanus was a staunch defender of the notion of a fixed term of life and we can assume that his addressee Marinus shared his views. Both men were undoubtedly members of the Constantinopolitan establishment. Germanus, who was possibly related to Emperor Justinian, had served as deacon in the administration of the patriarchate before he became metropolitan of Cyzicus and then patriarch of Constantinople. ${ }^{63}$ Marinus, who is called hypatos and antigrapheus in the title of Germanus' treatise, has plausibly been identified with one of the officials that were responsible for the compilation of the Ecloga ${ }^{64} \mathrm{He}$, too, was no homo novus: Germanus mentions that already his father had been highly educated. ${ }^{65}$ Moreover, it is worth noting that John of Damascus fits the same mould. He also stemmed from a family of bureaucrats, although the ruler he had served was not the Byzantine emperor in Constantinople but the Muslim caliph in Damascus. ${ }^{66}$ By contrast, it could be argued that Sophronius was a member of the old provincial elite. His closest parallel in the West would then be Gregory the Great, another local figure that emphasised the efficacy of the intercession of saints. ${ }^{67}$

Of course, one must be careful not to be too schematic. Not all authors may have held views that were as clear-cut as those of Germanus or Sophronius. In the case of Theophylact the level of personal engagement is almost impossible to gauge. Equally fraught is the interpretation of Biblical commentaries since their authors tended to reproduce existing explanations. Moreover, the different literary genres and the audiences that they addressed may have played a role. It is entirely possible that one and the same author wrote a sermon in which he stressed the ineluctability of death in order to induce his listeners to

62 See J. Haldon, Byzantium in the Seventh Century. The Transformation of a Culture, Cambridge, 1990, pp. 196-201, pp. 232-244.

63 See above note 3.

64 See L. Burgmann, Ecloga. Das Gesetzbuch Leons III. und Konstantinos' V (Forschungen zur Byzantinischen Rechtsgeschichte, 10), Frankfurt a. M., 1983, p. 104.

65 See Germanus, Terms of Life, ed. Garton and Lenderink, p. 4.17-18.

66 On John of Damascus see H. Kennedy, "Syrian Elites from Byzantium to Islam: Survival or Extinction?," in: Money, Power and Politics in Early Islamic Syria: A Review of Current Debates, ed. J. Haldon, Abingdon-New York, 2010, pp. 181-200.

67 On Pope Gregory see M. Dal Santo, Debating the Saints' Cult in the Age of Gregory the Great (Oxford Studies in Byzantium), Oxford, 2012. On Sophronius see Ph. Booth, above note 47. 
repent, and a hagiographical text in which he extolled the intercessory powers of a saint in order to kindle devotion for him. Finally, even if an author had a fixed opinion he may have held it for different reasons. A case in point is Maximus the Confessor, who states in his Quaestiones ad Thalassium:

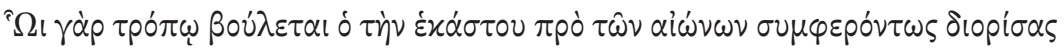

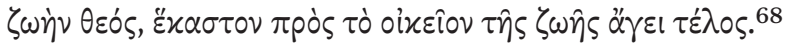

For how God who has fixed before the ages the life of each one in a beneficial manner wishes, he leads each one to his own end of life.

This passage shows that together with Germanus and John of Damascus, Maximus must be counted among the defenders of a fixed term of life. However, if we are to believe his Syriac biographer, Maximus was not a member of the elite but a son of humble parents who was socialised in the monasteries of Palestine. ${ }^{69}$ This suggests that other factors led him to reject the efficacy of intercession in the case of imminent death. That the authors of collections of Questions and Answers held the opposite view is also difficult to explain because in other contexts they were quite reserved about the cult of saints. ${ }^{70}$ Here lingering influences of the Antiochene School may have played a role: as we have seen, Diodore, Theodore and Theodoret had been among the staunchest defenders of a changeable term of life in Late Antiquity. ${ }^{71}$

Despite all these caveats, the interpretation that has been offered retains its validity. Indeed, it finds further confirmation in evidence from the late eighth and early ninth century. At that time the most prominent advocate of a fixed term of life was Theodore of Stoudios whose paternal and maternal ancestors

68 Maximus, Quaestiones ad Thalassium, 37, ed. C. Laga and C. Steel, Maximi Confessoris quaestiones ad Thalassium, I: Quaestiones I-LV (Corpus Christianorum. Series Graeca, 7), Turnhout-Leuven, 1980, p. 249.31-33. I would like to thank Grigory Benevich for having pointed out this passage to me.

69 S. Brock, "An Early Syriac Life of Maximus the Confessor", Analecta Bollandiana, 91 (1973), pp. 302-313.

70 See G. Dagron, "L'ombre d'un doute: L'hagiographie en question, $\mathrm{VI}^{\mathrm{e}}-\mathrm{XI}$ siècle," Dumbarton Oaks Papers, 46 (1992), pp. 59-68.

See D.S. Wallace-Hadrill, Christian Antioch. A study of early Christian thought in the East, Cambridge, 1982, pp. 112-114. Similar views were still held by the Nestorian patriarch Timothy, see. V. Berti, "Provvidenza, liberta e legame anima-corpo nella lettera 2 di Timoteo I a Rabban Bokhtišo', archiatra di Harun al-Rašid," in: Le vie del sapere in ambito siro-mesopotamico. Atti del convegno internazionale tenuto a Roma nei giorni 12-13 maggio 2011, ed. C. Noce, M. Pampaloni, C. Tavolier, Rome, 2013, pp. 149-175. 
had for several generations worked in the financial bureaucracy of the capital. ${ }^{72}$ By contrast, the efficacy of intercessory prayers for the dying was affirmed by provincial holy men and their hagiographers.

Theodore is best known for his principled stance in church politics: when he felt that emperors and patriarchs were breaking canon law or adulterating Christian doctrine he did not hesitate to break communion with them. ${ }^{73}$ However, he was also the head of two monastic communities, Sakkoudion in Bithynia and Stoudios in the capital, and the spiritual adviser of a large group of laypeople. ${ }^{74}$ In order to communicate his views he wrote numerous catecheses, hymns and letters. These texts permit us to reconstruct his thought-world to a much greater extent than has been possible for the previous period. The topic of the term of life is broached in a hymn that was sung by the monks at the funerals of their deceased brethren:

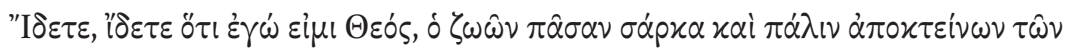

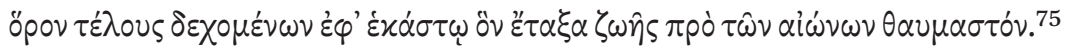

Behold, behold, that I am God, who vivifies and again kills all flesh of those who have received the term of the end of life, which I have wonderfully fixed for each one, before the ages.

These lines show that Theodore was an unequivocal defender of a fixed term of life who did not want his monks to be in doubt about such an important matter. By emphasising that the time of one's death had been determined before all ages he excludes the compromise view that is found in Theophylact's rhetorical exercise, namely that the lifespan of an individual always consists of a certain number of years but that God can always fix a new term by adding or subtracting a few years. Significantly, Theodore lets God himself speak, thus giving the statement the highest authority possible. The first half of the text is

72 On Theodore's family, cf. Th. Pratsch, Theodoros Studites (759-826) zwischen Dogma und Pragma (Berliner byzantinische Studien, 4), Berlin, 1998, pp. 18-29.

73 On Theodore's political activity see Pratsch, Theodoros Stoudites, pp. 81-113, pp. 147-176, pp. 203-234.

74 Cf. J. Leroy, Studitisches Mönchtum. Spiritualität und Lebensform, Graz, 1969.

75 Theodore of Stoudios, Funerary Canon, ode 2, ed. M. Arco Magrì, "Il canone in requiem monachi di Teodoro Studita," Helikon, $18 / 19$ (1978-1979), pp. 280-292.54-6o. 
indeed a Biblical quotation, taken from a passage that stresses the uniqueness and omnipotence of God. ${ }^{76}$ It is clear that Theodore considered the specific notion of a fixed term of life, which is non-Scriptural, to be a logical consequence of the Biblical concept of God.

In such a framework death cannot be staved off through prayer. Theodore makes this point in a letter to the Stoudite monks in exile:

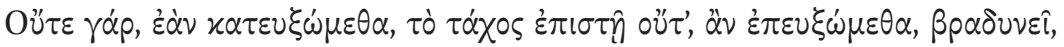

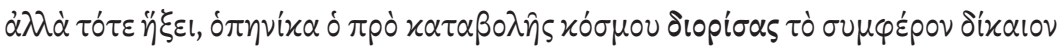

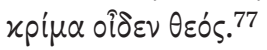

For neither does it come swiftly when we pray for it, nor does it tarry when we pray against it, but it will come then when God knows who fixed the profitable just judgement before the foundation of the world.

How the notion of a fixed term of life influenced Theodore's attitude towards death can be seen most clearly in a letter to the orphanotrophos Leo and his wife:

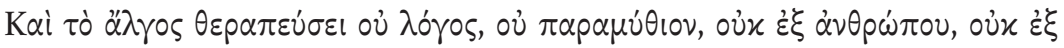

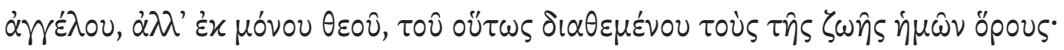

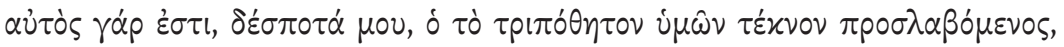

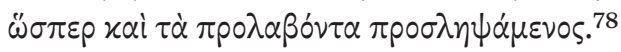

And the pain will be soothed not by a speech, not by a consolation, not by a human being, not by an angel, but by God alone who has thus fixed the term of our life, for he it is, my lord, who took your thrice-beloved child, as he had already taken the ones before.

Here the addressees are urged to accept that the death of their children was for the best. Interventions by human beings or even angels are useless. Consolation can only be found in the belief that it was God who acted and that God did so according to a predetermined plan.

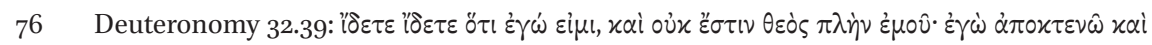

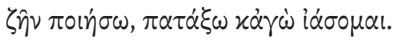

77 Theodore of Stoudios, Letters, 392, ed. G. Fatouros, Theodori Studitae Epistulae, I-II (Corpus Fontium Historiae Byzantinae. Series Berolinensis, 31.1-2), Berlin, 1992, vol. II, p. 544.49-51

78 Theodore of Stoudios, Letters, 29, ed. G. Fatouros, vol. I, p. 81.19-23. 
Unsurprisingly, Theodore also recommends the meditation of death. In his catecheses he tells his flock:

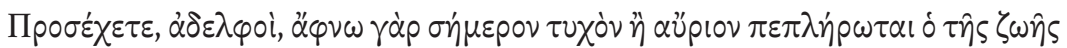

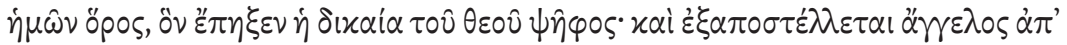

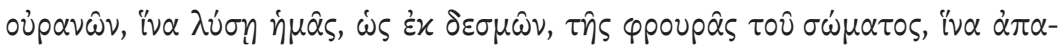

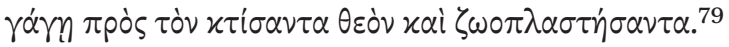

Take care, brothers, for today perhaps or tomorrow is suddenly completed the term of your life, which the just judgement of God has fixed, and an angel is sent from heaven in order to liberate you from the dungeon of the body as if from bonds and to lead you away to God who has created and vivified you.

Here the uncertainty of the hour of death acts as a goad for monks to be at all times at their best behaviour.

Thanks to Theodore's extensive literary legacy, we see for the first time a single person holding all beliefs associated with the discourse about the term of life. Even in his time, however, Theodore's case was exceptional. This makes it difficult to find parallels for his stance in texts of other authors. The only comparable material is found in the biographies of two abbots of the Bithynian monastery of Medikion, which were both written in the first half of the ninth century. In the Life of the founder of the monastery, Nicephorus, we encounter the same acceptance of the divine will as in Theodore's consolatory letter. When Nicephorus realises that the end of his life has come he says to his companions:

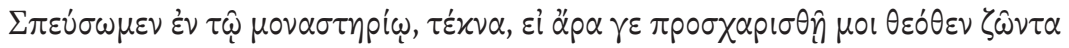

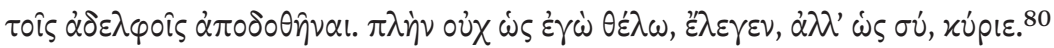

He said: 'Let us hurry to the monastery, children, if perhaps it is granted to me from God that I be returned to the brethren alive. However, not as I want but as you want, Lord.'

\footnotetext{
79 Theodore of Stoudios, Catechesis Magna, 70, ed. J. Cozza-Luzi, Theodori Studitae Sermones Catecheseos Magnae (Patrum Nova Bibliotheca, 9.2), Rome, 1888, p. 196.11-17.

$80 \quad$ Life of Nicephorus of Medikion, 18, ed. F. Halkin, "La vie de saint Nicéphore, fondateur de Médikion en Bithynie (+ 813)," Analecta Bollandiana, 78 (1960), p. 423.6-9.
} 
In the Life of Nicephorus' successor, Nicetas, by the monk Theosterictus we find a catechesis inserted into the text in which the monks of Medikion are told how important it is to be prepared for the hour of death: ${ }^{81}$

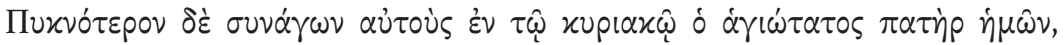

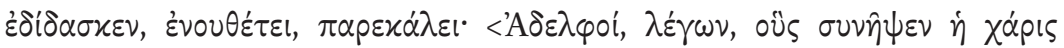

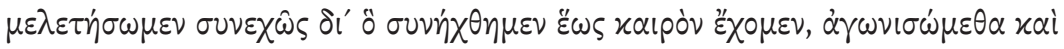

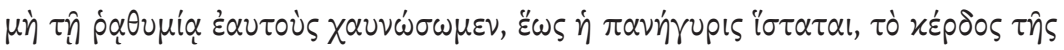

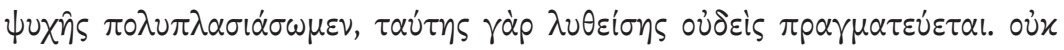

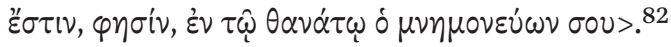

Frequently our most holy father gathered them in the church and taught, admonished and comforted them: 'Brethren whom grace has joined, let us meditate continually why we have come together as long as we have time, let us struggle and let us not become lax through negligence, let us multiply the gain of the soul as long as the fair lasts, for when it has been dissolved, nobody does business. As it is said: "There is nobody who remembers you in death."'

This evidence suggests that the hagiographers of Nicephorus and Nicetas, and most likely also the saints themselves, shared Theodore's world-view. Like Sakkoudion and Stoudios, Medikion was a strictly coenobitic community where life was organised according to an intricate set of rules. ${ }^{83}$ Thus one might argue that the notion of a fixed term of life is linked to the coenobitic ideology. However, this interpretation does not invalidate our previous argument. Nicephorus, the first abbot of Medikion, was also a member of the Constantinopolitan elite, which suggests that preference for the coenobitic life-style was the result of the founders' socialisation as bureaucrats in the capital.

In order to find evidence for the opposite position we need to turn to contemporary biographies of holy men. Most informative is the Life of Peter of Atroa

81 On author and text see J.O. Rosenqvist, "A Philological Adventure. Editing the Life of St. Niketas of Medikion," Acta Byzantina Fennica, n.s., 1 (2002), pp. 59-72.

82 Theosterictus, Life of Nicetas of Medikion, 15, AASS, Aprilis, I: Dies 1-10 (Paris $\left.{ }^{2} 1866\right)$, p. xxi.

83 On Medikion see P. Hatlie, The monks and monasteries of Constantinople (c. 350-c.850), Cambridge 2007, pp. 283-284. 
by the monk Sabas, which dates to the Second Iconoclasm. ${ }^{84}$ In one of the episodes the saint is called to the house of a local worthy who is seriously ill:

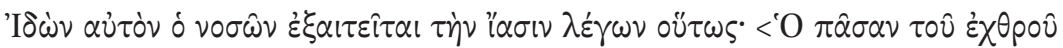

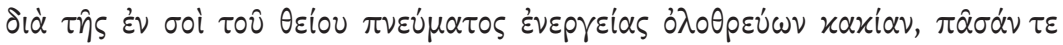

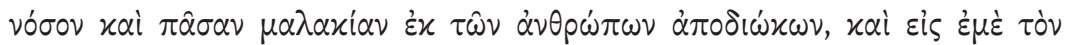

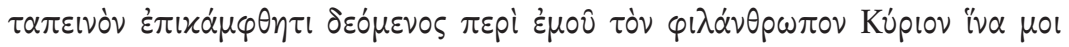

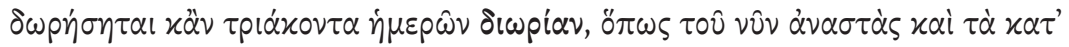

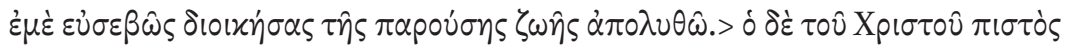

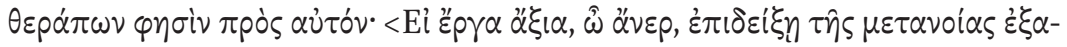

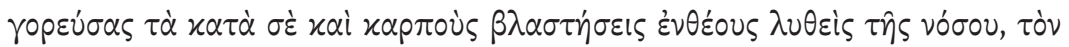

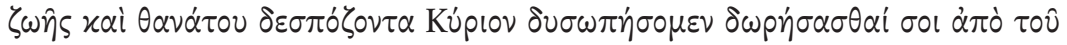

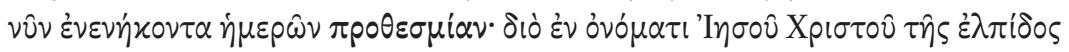

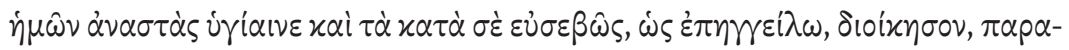

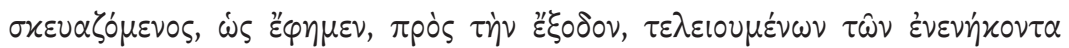

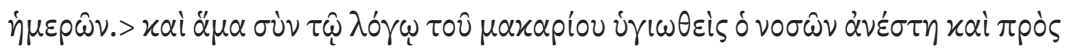

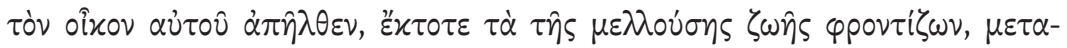

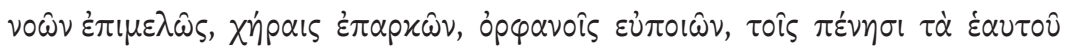

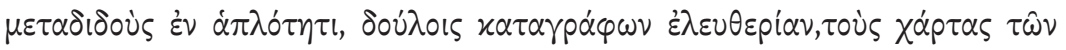

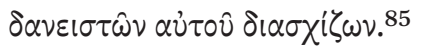

When the patient sees him he asks for a cure with the following words: 'You who destroy all evil of the enemy through the operation of the divine spirit in you, who drive away all illness and weakness from human beings, show mercy and entreat for me the merciful Lord that he may give me a reprieve of just thirty days, so that I can rise now, and after having settled my affairs in a pious fashion, be liberated from this present life.' The faithful servant of Christ says to him: 'Man, if you show proper works of repentance after having confessed what concerns you, and put forth divine fruits after having been liberated from the illness, let us entreat the Lord who is master over life and death, that he grant you from now on a reprieve of ninety days. Therefore, in the name of Jesus Christ, our hope, rise and be hale and as you have promised, settle your affairs in a pious fashion, so that you are prepared, as we have said, for the departure, when the ninety days are over.' And while the blessed one was saying this the ill one was cured and stood up and went to his house, and from then he

\footnotetext{
84 On the author see V. Laurent, La vie merveilleuse de saint Pierre d'Atroa (Subsidia Hagiographica, 29), Brussels, 1956, pp. 9-15.

85 Sabas, Life of Peter of Atroa, 53, ed. Laurent, pp. 171.24-173.43.
} 
concerned himself with the life-to-come, studiously repenting, giving to widows, making gifts to orphans, distributing his possessions to the poor in simplicity, giving freedom to slaves, tearing up the chits of the usurers.

Here we are in the presence of a completely different mindset. It is claimed that God can change the term of life of a human being and that he does so when entreated by a holy man. As a consequence, the dying react in a radically different fashion: instead of stoically accepting death as an expression of divine providence they actively seek help. What troubles them is not death itself but the fear of dying unprepared. Here the holy man can offer a service. He persuades God to grant the dying enough time to do all the things that are considered necessary for the salvation of their souls.

Like Theodore, Sabas emphasises the omnipotence of God. However, he does then not draw the conclusion that it is only God who acts. Instead he contends that a holy man can tap into this power. Peter's influence is so great that he even secures a longer timespan for the dying than had been asked for. An even more extreme attitude is found in another episode. There Sabas describes an illness of the saint from which he recovered against all expectation and then adds the following comment:

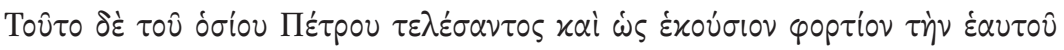

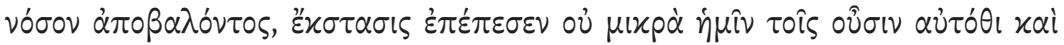

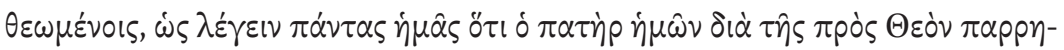

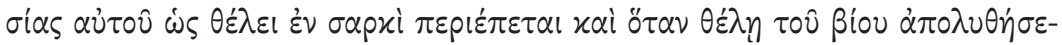
$\tau \alpha{ }^{8}{ }^{86}$

When the holy Peter had done this and shaken off his illness as if it were a voluntary burden, great wonderment befell us who were there and saw it, so that all of us said: 'Through his outspokenness before God our father remains in the flesh as he wills and will be liberated from this life when he wills.'

Here the unexpected recovery engenders in the monks the belief that Peter is the master of his own death. The crescendo that leads from a change of the term of life to its complete removal has a precedent in Sophronius' Miracles of

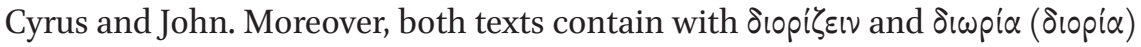
similar technical terms for the extension of a person's lifespan. This suggests that we can draw a direct line from Sophronius to Sabas, just as we could from 
Germanus to Theodore of Stoudios. The turbulent years of the Dark Age do not seem to have led to a major disruption of the discourse.

There can be no doubt that the representatives of the two camps were aware of each other. Indeed, there is evidence, which suggests that they clashed. It is found in the Life of Joannicius, the most famous holy man of the time. Joannicius' hagiographer, Peter, tells us that the saint predicted the death of the steward of a convent but that a group of Stoudite monks led by Theodore's disciples Athanasius and Naucratius interfered. They convinced the abbess that a person's time of death cannot be known by a human being and thus tried to prevent the man from making the necessary preparations:

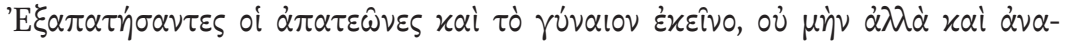

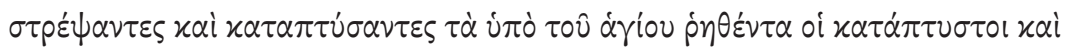

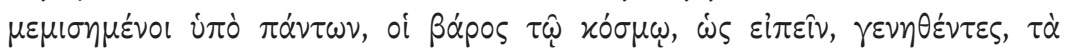

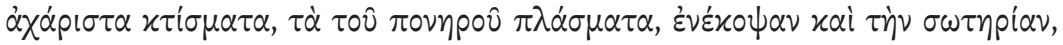

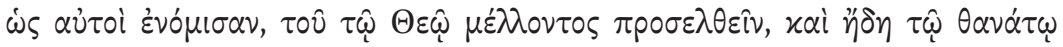

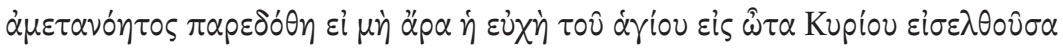

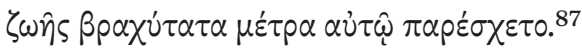

So those deceitful monks fooled also that woman; and, in addition, these people who should be spat upon and hated by all, who are weights on the world, so to speak, graceless creations, fabrications of the devil, turned upside down and spat upon the saint's words; they tried to hinder, so they thought, the salvation of the man who was about to depart to God. And he would already have been delivered over to death unrepentant if the saint's prayer had not come to the ears of the Lord and furnished him the briefest additional measure of life. ${ }^{88}$

At the end of this very polemical passage the hagiographer declares that Joannicius not only knew the time of death but could even change it. No mention is made of a response of the Stoudite monks but we can be sure that this further-reaching claim was also rejected by them.

The texts analysed so far suggest that there was a clear dichotomy between members of the Constantinopolitan elite and provincial holy men and their

87 Peter, Life of Joannicius, 57, ed. J. van den Gheyn, Acta Sanctorum Novembris II.1 (Brussels, 1894), p. 422A.

88 Translation by D.F. Sullivan, "Life of St. Ioannikios," in: Byzantine Defenders of Images. Eight Saints' Lives in English Translation, ed. A.-M. Talbot (Byzantine Saints' Lives in Translation, 2), Washington, DC, 1998, p. 323. 
followers. The former defended the notion of a fixed term of life whereas the latter rejected it. In reality, however, the fault-lines were most likely not so clear-cut. At this point we need to turn to another important figure of the time, Methodius, the later patriarch of Constantinople. A native of Syracuse, he had come to the capital in order to make a career but had then taken holy orders and become a member of the clergy of St Sophia. ${ }^{89}$

Methodius broaches the issue twice in his oeuvre, in the Encomium of Agatha and in a hymn that he wrote in honour of his patron saint Lucy. In the former text he has Agatha pray for release from her body, a prayer that is immediately granted. ${ }^{90}$ In the latter text we read:

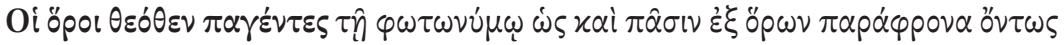

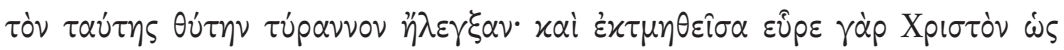

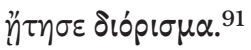

The terms that had been fixed for the light-named, as they have been for everybody else, did indeed reveal her sacrificer, the tyrant, to be deranged and 'off limits', because even beheaded she found a reprieve as she had asked Christ.

This passage is not easy to understand. The argument appears to rest on the idea that Lucy did not die immediately when she was beheaded, a detail that is not mentioned in the surviving accounts of Lucy's martyrdom but has close counterparts in other texts such as the Passio of Denys of Paris. ${ }^{92}$ The explanation for this 'miracle' is offered in the last sentence where Methodius states

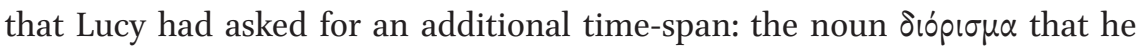

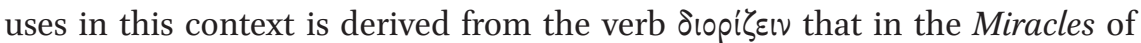
Cyrus and John denotes the granting of an extension and must thus be regard-

89 On Methodius see B. Zielke, "Methodios I.", in: Patriarchen der ikonoklastischen Zeit, ed. Lilie, pp. 183-26o.

90 Methodius, Encomium of Agatha, 28, ed. E. Mioni, "L'encomio di S. Agata di Metodio patriarcha di Costantinopoli," Analecta Bollandiana, 68 (1950), pp. 58-93, esp. p. 90.

91 Methodius, Canon on Lucy, 29.29, ed. A. Kominis, G. Schirò, Analecta hymnica graeca e codicibus eruta Italiae inferioris, IV: Canones Decembris, Rome, 1976, p. 287.8-13. Compare the Passio of Julian et Basilissa, 47, ed. F. Halkin, "La passion ancienne des saints Julien et

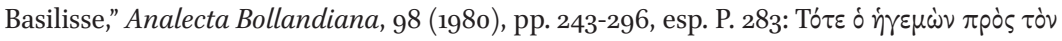

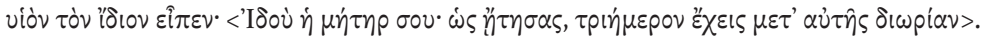

92 See J.C. Westerbrink, Passio S. Dionysii Areopagitae, Rustici et Eleutherii, uitgegeven naar het Leidse Hs. Vulcanianus 52, Alphen, 1937, esp. p. 60. 
ed as a synonym of $\delta \omega \omega p^{\prime} \alpha\left(\delta 10 p^{\prime} \alpha\right)$, which appears in the Life of Peter of Atroa. ${ }^{93}$ Thus Methodius can conclude that Lucy's torturer had calculated wrongly. The background for this curious theory can be found in the teachings of PseudoEusebius of Alexandria, which we discussed earlier: demons can guess the limit of a person's life and can therefore use wild animals or evil humans in order to kill this person at this particular point in time. In Lucy's case this strategy did not work because Christ had changed the originally envisaged term of life.

This raises the question: why did Methodius in this matter side with the holy men and their devotees against members of the Constantinopolitan elite? A possible answer presents itself when we consider contemporary church politics. As is well known Methodius had problems with the recalcitrant Stoudites and could count on the support of Joannicius and other holy men. ${ }^{94}$ Yet it is not clear whether the political alliance led to a convergence of view-points or whether it was not rather an existing ideological affinity that facilitated group formation.

The discussion so far has shown that the debate about the term of life continued unabated from the late sixth to the early ninth century and that both views can be linked to specific social milieus. The champions of a fixed term of life were found among the bureaucratic elite in Constantinople whereas their opponents seem to have represented groups that were further removed from the centre of power. The historical context for the discourse was the near-collapse of the Late Roman world order and the slow emergence of new structures.

The middle of the ninth century proved a caesura not only for the controversy about the cult of icons but also for the debate about the term of life. This is at least suggested by the surviving sources. Although they are far more numerous they hardly ever contain discussions of the topic. Moreover, the few relevant texts give the impression that the defenders of a changeable term of life had gained the ascendancy over their adversaries. To my knowledge there is only one text that advocates the notion of a predetermined life-span, a section of Photius' Amphilochia. However, this text is simply a copy of Germanus' dialogue, which makes it difficult to interpret as an expression of Photius'

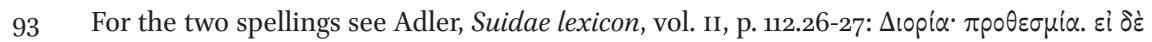

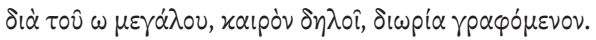

94 See E. von Dobschuetz, "Methodios und die Studiten. Strömungen und Gegenströmungen in der Hagiographie des 9. Jahrhunderts," Byzantinische Zeitschrift, 18 (1909), pp. 41-105. 
thought. ${ }^{95}$ All other texts take the opposite stance. Patriarch Nicholas Mystikos had this to say about the topic:

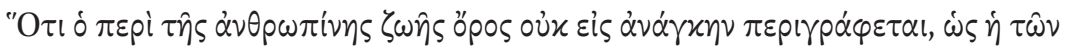

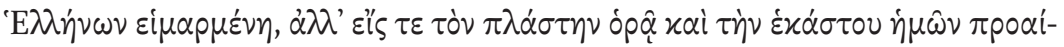

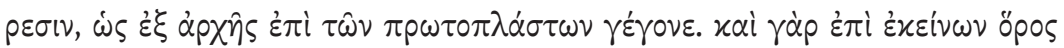

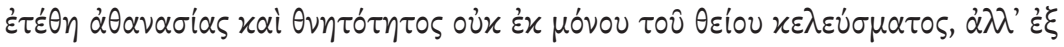

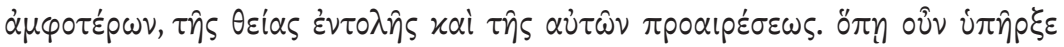

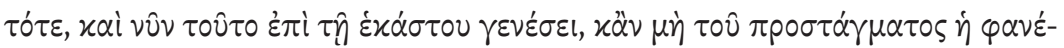

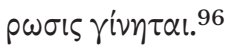

That the term of human life is not circumscribed by necessity, like the fate of the pagans, but is related to the creator and the free will of each of us, as it was the case at the beginning with the first-created ones. For in their case a term was set of either immortality or mortality, which was based not only on the divine command, but on both, the divine commandment and their free will. As it was then, so it is now in the case of the birth of each one, even if there is no disclosure of the command.

This passage is a fragment of a longer text and its original context is unknown. Nevertheless, it is immediately obvious that we have entered a different world. Nicholas recycles arguments of the champions of a changeable term of life and again speaks about astrological determinism as if the debate of the previous three centuries had not taken place. He argues that the death of Adam and Eve was a result of their sin and that in our case, too, God takes into account our conduct when he allots us our lifespans. Nicholas' stance is significant because he was not only a former bureaucrat but also a relative of Photius. ${ }^{97}$

Even more significant is the fact that the monastic elite of Stoudios went over to the other camp. In the early tenth century, one of their number, the monk Michael, wrote a biography of Theodore the Stoudite, the so-called Vita $B$, which was intended for use in the community. This text includes one passage, which describes how the saint was supposed to have reacted when one of his monks was so sick that he wished to die:

95 See Lackner, Gegen die Vorherbestimmung, p. liii.

96 Nicholas Mystikos, Fragments, 199.xxii, ed. L.G. Westerink, Nicholas I, Patriarch of Constantinople, Miscellaneous Writings (Corpus Fontium Historiae Byzantinae. Series Washingtonensis, 20), Washington, DC, 1981, p. 50. 


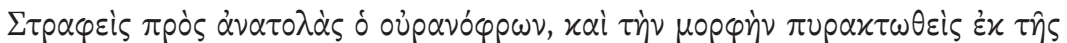

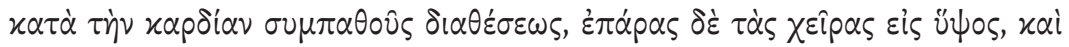

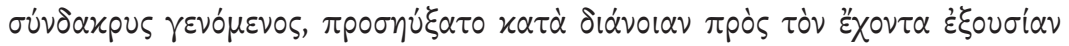

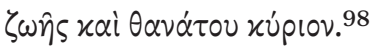

When the celestially-minded had turned to the East and had become inflamed as regards his appearance from the merciful attitude of his heart and had lifted up his hands and had become tearful, he prayed in his mind to the lord who has authority over life and death.

According to the hagiographer this prayer was effective. The sick monk died the very moment that Theodore had concluded his prayer. One can imagine how galling Theodore would have found such a portrayal of himself. Further evidence of this sea-change is found in two texts of Stoudite provenance that date to the same years, the Life of Evaristus of Kokorobion and the Life of Blaise of Amorion. ${ }^{99}$

Evaristus had entered the community of Stoudios in his youth when Theodore's disciple Naucratius was still abbot. Later he became a typical holy man, or is at least presented in this fashion by his hagiographer. In one of the miracle stories a man who had been given up by the physicians comes to the saint and asks for an extension of life so that he can make the necessary arrangements. Evaristus makes a show of humility but then gets down to business:

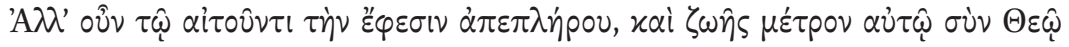

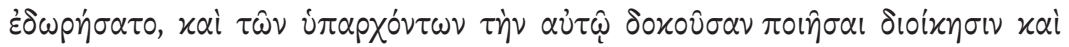

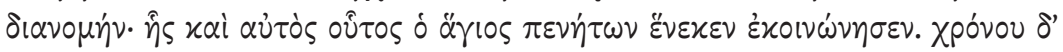

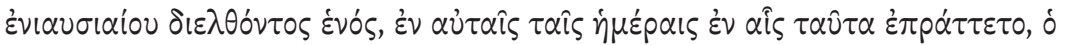

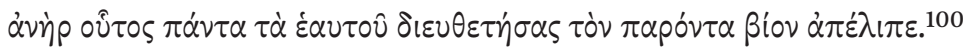

98 Michael the Monk, Vita B of Theodore of Stoudios, PG 99, col. 309B1-12. On the author see D. Krausmüller, "Vitae $B, C$ and $A$ of Theodore the Stoudite: their Interrelation, Dates, Authors and Significance for the History of the Stoudios Monastery in the Tenth Century", Analecta Bollandiana, 131 (2013), pp. 280-298.

99 On the Lives of Euarestus and Basil, see S. Efthymiadis, "Hagiography from the 'Dark Age' to the Age of Symeon Metaphrastes (Eighth-Tenth Centuries)," in: The Ashgate Research Companion to Byzantine Hagiography i: Periods and Places, ed. S. Efthymiadis (Ashgate Research Companions), Farnham-Burlington, 2011, pp. 118-119.

100 Life of Euarestus of Kokorobion, 31, ed. C. van de Vorst, "La vie de s. Évariste, higoumène à Constantinople," Analecta Bollandiana, 41 (1923), pp. 288-325, esp. p. 316.32-37. 
But he fulfilled the wish of him who asked and granted him with God a measure of life that he might dispose of and distribute his belongings to his own satisfaction. In this the saint himself participated for the sake of the poor. And when a year had passed, this man departed from this life after he had settled all his affairs, during the same days in which this had happened.

It is evident that Evaristus behaves just as Peter and Joannicius had done a century earlier. When we turn to the Life of Blaise we encounter a similar situation. The text contains a miracle story where a monk of Stoudios who is about to die has the following vision:

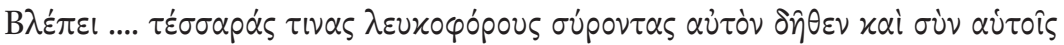

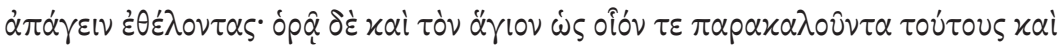

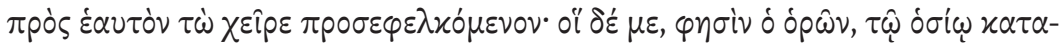

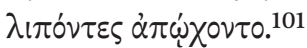

He sees ... four figures in white clothes who seemingly drag him and want to take him with them, and he also sees the saint as if beseeching them and pulling the hands towards himself. The others departed, the one who had the vision said, leaving me to the saint.

This interaction conforms to a template that we have already found in the Miracles of Cyrus and John and in the Life of Theodore of Sykeon: angels coming to collect the soul of a dying person are prevented from doing so by a saint. There is, however, one important difference between the texts. Blaise's hagiographer makes no use of technical terms such as 'term of life' and 'reprieve' and he gives no indication that what he is saying could have been in any way controversial.

Thus we get the impression that in the century after Iconoclasm there was almost universal agreement that the term of life is changeable. This raises the question: how did this situation come about? In the case of the Stoudites one could argue that the collective memory of the community had been weakened in the years of Photius' patriarchate when interlopers served as abbots. ${ }^{102} \mathrm{How}^{-}$ ever, no such explanation is possible for the views of Nicholas Mystikos, since the imperial administration did not undergo dramatic changes. A satisfactory p. 667 BC. 
answer can only be found if we manage to get a clearer sense of the processes of social and cultural change that unfolded after the Triumph of Orthodoxy. Nevertheless, one can ask: could it be that the periphery had gained a victory over the centre?

It would, however, be wrong to conclude that the debate had disappeared for good, because it was rekindled in the eleventh century. The most important evidence for this renewed interest is a treatise about the term of life by the Stoudite monk Nicetas Stethatos. ${ }^{103}$ This treatise is the first lengthy discussion of the issue since the early eighth century. Moreover, it is not an academic exercise but a polemical response to an attack by a layman called Manuel. ${ }^{104}$ The best starting point for a discussion is the introduction to the treatise:

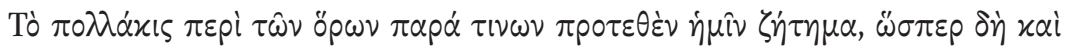

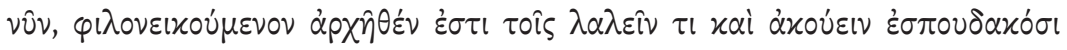

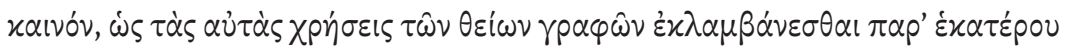

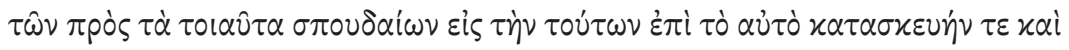

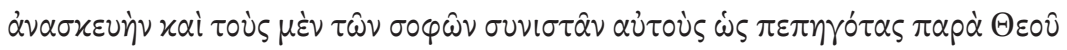

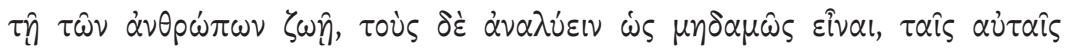

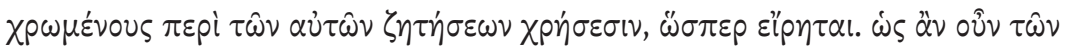

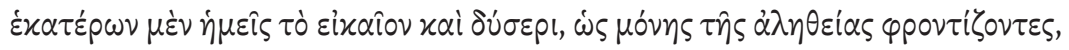

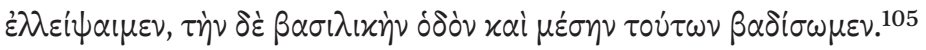

The question about the terms, which has often been put to us by some people, just as it is now, has been controversial from the beginning among those who strive to say and hear something new. ${ }^{106}$ The same quotations from the divine Scriptures are used by both sides that are interested in this matter in order to build them up or tear them down. One group of

\footnotetext{
103 On Nicetas Stethatos, see D. Krausmüller, "Establishing Authority in the Constantinopolitan Religious Discourse of the Eleventh Century: Inspiration and Learning in the Writings of the Monk Niketas Stethatos", in: Networks of Learning: Perspectives on Scholars in Byzantine East and Latin West, c.100o-120o, ed. S. Steckel, N. Gaul, M. Grünbart, Berlin-Münster, 2014, pp. 107-24.

104 Nicetas Stethatos, To Manuel, About the Terms of Life, ed. J. Darrouzès, Nicétas Stéthatos, Opuscules et Lettres. Introduction, texte critique, traduction et notes (Sources Chretiennes, 81), Paris, 1961, pp. 366-410.

105 Nicetas, Terms of Life, 1, ed. Darrouzès, p. 366.1-13.

106 See Acts 17.21.
} 
wise men affirms them as being fixed by God for the life of human beings whereas the other group refutes them as not existing at all, using the same quotations for the same issues, as has been said. In order that we avoid the arbitrariness and contrariness of both, since we only care for the truth, let us walk the royal road, which is in the middle of them.

Here Nicetas presents his own position as the golden mean between two equally reprehensible extremes. The first part of the treatise is taken up by a vicious polemic against those who believe that there is no fixed term of life at all. Nicetas declares that only God is without bounds and that it would be blasphemous to attribute the same property to human beings. ${ }^{107}$ Then he suddenly changes tack and starts attacking those who declare that the term of life is completely unchangeable. At this point Nicetas' own point of view emerges. It is the intermediate position that the lifespans of human beings are fixed but that God can add to or subtract from the predetermined number of years whenever he sees fit. ${ }^{108}$ Such a threefold distinction is not without precedent. As we have seen it is already found in Theophylact's rhetorical exercise.

It is not immediately clear from the text what position the layman Manuel held. He cannot have argued at the same time that there is no fixed term of life at all and that the term of life is fixed and cannot be moved. Since Nicetas devotes much more space to the refutation of the latter point of view it seems likely that this was what Manuel actually believed. This raises the question: why does Nicetas not simply juxtapose his position with that of Manuel but instead feels the need to introduce a threefold distinction? One possible explanation would be that the notion of a flexible term of life was being considered problematic again and that Nicetas wished to deflect attacks by introducing an even more extreme position from which he could then distance himself.

This interpretation gains further support when we consider how Nicetas deals with proof texts. Unlike his predecessors he quotes a great number of passages from Patristic literature. However, pride of place is given to two texts, Basil's sermon Quod deus non sit auctor malorum and Theodore of Stoudios' hymn for the funeral of a monk:

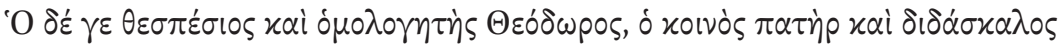

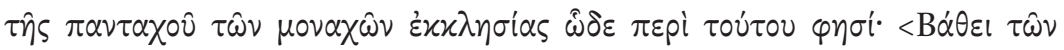

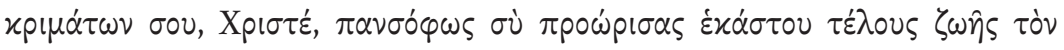

107 Nicetas, Terms of Life, 2-12, ed. Darrouzes, pp. 368-376.

108 Nicetas, Terms of Life, 15-17, ed. Darrouzès, pp. 378-382. 


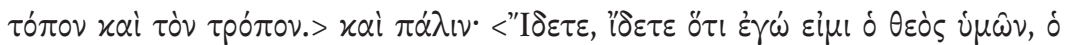

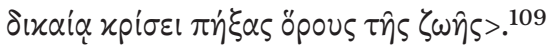

The venerable confessor Theodore, the common father and teacher of the church of monks everywhere, says this about the topic: 'Through the depth of your judgements, Christ, you have most wisely predetermined the place and the manner of the end of life of each one,' and again: 'Behold, behold, that I am your God who has fixed the terms of life though a just judgement.'

Nicetas claims that these texts support his own position and attacks his adversary for having wilfully misunderstood their real meaning. This is a decidedly odd argument, because Basil's statement had always been the pièce de résistance of the champions of a fixed term of life, and Theodore's hymn, too, could only be used in this way. ${ }^{110}$ This suggests that Manuel had referred to these two texts and that he had presented them as evidence for his own point of view. If this interpretation is correct either Manuel or an earlier author would have excerpted Theodore's hymn. By doing so he could not only broaden the evidence base but also capitalise on Theodore's status as a prominent defender of icon worship. ${ }^{111}$ For a Stoudite monk like Nicetas who no longer agreed with Theodore's opinion, such a strategy was particularly irksome because by rights it should have forced him to challenge the authority of his revered patron saint. That he was not prepared to do so is hardly surprising. To escape his predicament he created an extremely convoluted argument, which was meant to pull wool over the eyes of his readers. ${ }^{112}$

The discussion so far may have given the impression that the references to the deniers of any term of life are merely a rhetorical ploy and that nobody actually held such a position at the time. However, this is not the case, as can

109 Nicetas, Terms of Life, 31, ed. Darrouzès, p. 394.1-7.

110 It is worth noting that Nicetas presents a truncated version of Theodore's sentence: the detail that the term of life is fixed before all ages is suppressed.

111 A combination of Basil's and Theodore's statements is also found in an anonymous treatise on predetermination of uncertain date. See P. Van Deun, E. Gielen, "The Metochion, Holy Sepulcre 363 Manuscript and an Unpublished Byzantine Opuscule on Predetermination," in: Fate, Providence and Moral Responsibility in Ancient, Medieval and Early Modern Thought. Studies in Honour of Carlos Steel, ed. P. d'Hoine, G. Van Riel, Leuven, 2014, pp. 395-417.

112 Misunderstood by Lackner, Gegen die Vorherbestimmung, pp. lvi-lvii, who thinks that Nicetas' argument is incoherent. 
be seen from Michael Psellos' Chronographia. In the section about Empress Theodora Psellos makes the following comment:

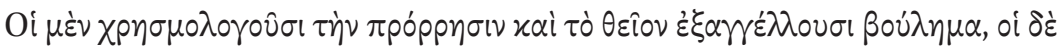

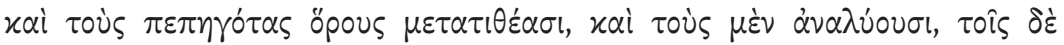

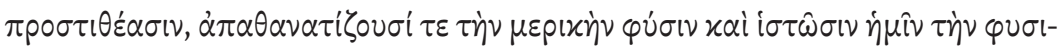

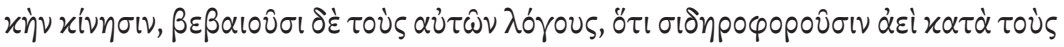

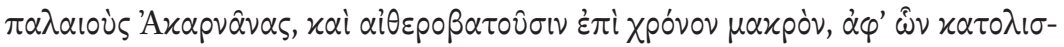

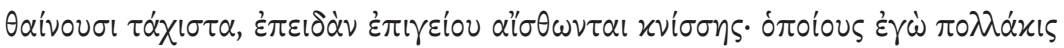

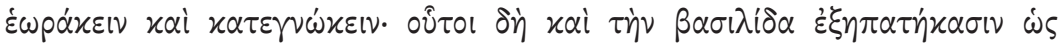

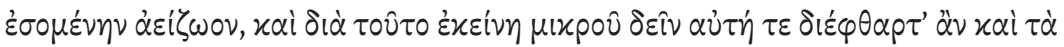

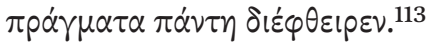

The ones utter prophecies and pronounce the divine will whereas the others even move the fixed terms, and dissolve them or add to them, and they immortalise the partial nature and bring to a standstill the natural movement, and they confirm the truth of their words through the fact that they continually bear irons like the old Acarnanians, and walk in the air for a long time, from where they rapidly slip down when they smell the fat of earthly sacrifices. Those I have often seen and condemned. They, then, deceived the empress telling her that she would live forever, and therefore she herself would almost have been corrupted and the affairs of the state were certainly corrupted.

Here we encounter the real extremists, the heirs of a tradition that stretches back to the seventh century when Sophronius claimed in his Miracles of Cyrus and John that the life-time of an individual could be without limits. Psellos is clearly scandalised by these men who on the strength of their asceticism claim for themselves the power to make a person immortal. This suggests that Nicetas felt the need to distance himself from contemporary holy men because he wished to be taken seriously by members of the secular elite.

To conclude: The question whether the time of death was fixed from eternity or could be moved became the focus of a controversy that pitted against each other two groups with radically different views about God and his relation with

113 Psellos, Chronographia, Theodora, 18, ed. É. Renauld, Michel Psellos, Chronographie, ou histoire d'un siècle de Byzance (976-1077) (Collection Bude), Paris, 1928, vol. II, pp. 80-81.12-25. 
creation. One group contended that God's providence was all-encompassing and that whatever happened was beneficial to human beings and therefore had to be accepted by them without demur. The other group claimed that God could change his mind and that it was therefore possible to negotiate with him. This was not merely an academic debate since it had implications for the lives of ordinary Christians. The second group argued that the saints could through their intercessions extend the lives of the dying and that the additional timespan could then be used for repentance and good works. The first group rejected such a view. It implicitly, and sometimes even explicitly, denied that the saints had such powers, and it used fear of an unexpected and ineluctable death as a means for moral improvement. It is arguable that the two points of view were related to particular socio-political ideals: a state where the ruler governs according to fixed laws and through the mediation of loyal officials and where the periphery passively accepts whatever is decided in the centre; or a state where the emperor is open to lobbying from the periphery and where the influence of powerful private individuals can undermine regular administrative processes. The former point of view was found among elite bureaucrats in the capital who identified closely with the emperors and their interests, whereas the latter point of view seems to have been held by people who represented particularistic interests. The debate started in the late sixth century when a new discourse with its own rules and conventions came into existence. At its centre was a quotation from a sermon by Basil of Caesarea in which the existence of an immovable term of life was affirmed. Significantly Basil's point of view was quite uncommon in Late Antiquity, when the vast majority of authors took it for granted that God could change his mind and regarded the belief in a fixed term of life as a pagan error. This suggests that during the 'Dark Age' a new worldview emerged whose proponents felt so strongly about their convictions that they polemicised against those who continued to adhere to the traditional view. The debate continued without break into the ninth century. In the decades following the end of Iconoclasm, however, it is no longer traceable in the sources. One gets the impression that the defenders of a changed term of life had succeeded in silencing their adversaries. This situation only changed in the eleventh century when their position again came under attack. What factors influenced the reappearance of the debate can only be established through more comprehensive studies of socio-political change in Byzantium. 